\title{
O eleitor antipetista: partidarismo e avaliação retrospectiva
}

$\begin{array}{r}\text { Denise Paiva } \\ \text { Silvana Krause } \\ \text { Adriana Paz Lameirão } \\ \hline\end{array}$

\section{Introdução}

As principais funções desempenhadas pelos partidos políticos nos governos democráticos são mobilizar e integrar eleitores, estruturar a competição política na arena eleitoral, além, é claro, da atividade governativa. A política partidária se constitui em pedra angular para a formação e a atuação dos governos democráticos. Uma das facetas desse fenômeno político é a vasta produção acadêmica que analisa a relação entre partidos e eleitores. Nos anos mais recentes, grande parte desses estudos tem se dedicado a investigar o arrefecimento dos vínculos entre eleitores e partidos, seus desdobramentos e impactos sobre os regimes democráticos. Os efeitos desse afastamento entre partidos e eleitores têm apresentado várias facetas como o desalinhamento partidário, o partidarismo negativo e um antipartidarismo mais extremo. O antipartidarismo é um fenômeno multifacetado, que pode decorrer da crença do eleitor de que a sua maneira de pensar não é representada por nenhum partido existente, de uma indiferença ou ainda do desencanto deste em relação à política e, em consequência, uma rejeição generalizada e radical aos partidos enquanto organização política. Ainda com a preocupação de compreender posicionamentos de rejeição aos partidos, estudos têm destacado uma rejeição específica a determinados partidos políticos, designado por alguns autores como identidade partidária negativa. Neste artigo, pretendemos analisar essa última dimensão, vinculada ao tema em tela, no que diz respeito ao Partido dos Trabalhadores (PT).

Muitas análises já foram feitas sobre o PT e o petismo em suas diversas dimensões, inclusive sobre o fato de ele ser a legenda que, tradicionalmente, apresenta os maiores percentuais de preferência partidária. Propomos um caminho inverso: investigar o antipetismo, compreendido como a rejeição a esse partido de forma específica. Várias questões ainda estão sendo investigadas e analisadas a respeito desse fenômeno que emerge no contexto brasileiro atual, por exemplo, a consideração de que a legenda esteve à frente do governo federal no período compreendido entre 2003 e 2016, até o afastamento da presidente Dilma Rousseff por meio do impeachment em 31 
agosto, uma variável que pode impactar a aprovação ou rejeição ao partido incumbente, bem como a avaliação das políticas implementadas ao longo de mais de uma década ${ }^{1}$.

Com base no questionário do Estudo Eleitoral Brasileiro (Eseb), realizado em $2014^{2}$, definimos como eleitor antipetista, para fins de nossa pesquisa, somente aquele que respondeu não gostar de jeito nenhum e exclusivamente do $\mathrm{PT}^{3}$. Estudos têm apontado para a crescente complexidade das dimensões e relações que são estabelecidas entre o eleitor e as organizações partidárias. Partimos da compreensão da literatura especializada de que o eleitor que rejeita absolutamente um único partido específico se diferencia daquele que rejeita vários, ou todos. Reconhecendo esse pressuposto, da não semelhança, envidamos esforços metodológicos para traçar o perfil do eleitor antipetista de forma mais acurada. Para isso, através de uma "filtragem" das respostas, dividimos o universo dos entrevistados que responderam não gostar de jeito nenhum do PT em outros dois, separando aqueles que manifestaram rejeição absoluta somente pelo PT (os antipetistas) daqueles que rejeitaram radicalmente todos os partidos (os antipartidários).

Se já são escassos os trabalhos que analisam o antipartidarismo, são ainda mais raros aqueles que examinam o antipetismo. Por esse motivo, nosso artigo tem um caráter inovador e busca descrever o antipetista com forte rejeição ao PT, desconsiderando, dessa análise, as gradações mais tênues do antipetismo. Pretende-se, primeiramente, identificar e traçar o perfil do eleitor antipetista e antipartidário de forma comparativa e, para levar a cabo esse objetivo, utilizamos a estatística descritiva. Em um segundo momento, a partir dos resultados da estatística descritiva, desenvolvemos um modelo de regressão logística ajustado com variáveis instrumentais ${ }^{4}$, a fim de detectar quais variáveis são determinantes para o respondente ser identificado como antipetista.

Duas hipóteses norteiam o estudo: a primeira é a de que o antipetismo pode ser explicado por uma avaliação negativa do eleitor sobre o governo petista em nível federal. A segunda hipótese é a de que se trata de um sujeito que nutre um sentimento positivo (possui alguma ou alta simpatia) em relação ao PSDB (Partido da Social Democracia Brasileira) e, além disso, tem preferência partidária por esse partido.

$\mathrm{O}$ artigo está dividido em quatro partes, além desta introdutória. Na primeira, realizamos um breve resgate do tratamento da literatura sobre partidarismo, antipartidarismo e identidade partidária negativa. Na segunda, tratamos da trajetória das

\footnotetext{
${ }^{1}$ As constantes e crescentes denúncias de corrupção envolvendo integrantes do PT muito provavelmente engendram um efeito reativo no eleitor em relação à sigla. No entanto, essa conexão não será investigada neste artigo, uma vez que o questionário Eseb 2014 não contempla perguntas que nos permitam fazê-lo.

2 Ver informações sobre o Eseb, sua amostra e período de realização em "Nota metodológica", no Apêndice.

3 Os entrevistados receberam uma cartela com a lista dos partidos e responderam à seguinte pergunta: "Agora gostaria de saber com mais detalhes o que o(a) sr(a). pensa sobre alguns partidos políticos. Por favor, para cada partido que eu citar, gostaria que atribuísse uma nota de 0 a 10 , sendo que 0 significa que $o(a) \operatorname{sr}(a)$. não gosta de jeito nenhum do partido e 10 que o(a) $\operatorname{sr}(a)$. gosta muito. Se eu falar o nome de um partido que o(a) $\operatorname{sr}(a)$. não conhece, apenas diga que não o conhece".

${ }^{4}$ Ver informações sobre o modelo no Apêndice, em "Nota metodológica".
} 
preferências partidárias no Brasil e de como o tema tem sido abordado. Na terceira parte, inicialmente traçamos o perfil dos eleitores antipartidários e antipetistas, observando suas bases socioeconômicas e regionais; em seguida analisamos a contribuição das variáveis selecionadas para a probabilidade de o eleitor ser antipetista. Na seção final, tecemos algumas considerações finais.

\section{Preferência partidária, partidarismo, antipartidarismo e identidade partidária negativa}

As análises da ciência política que tratam dos vínculos entre os eleitores e as organizações partidárias abarcam um leque multidimensional de investigações, que buscam identificar os determinantes da formação das preferências partidárias e do partidarismo (Campbell et al., 1960; Converse, 1964; Downs, 1957; Fiorina, 1981; Himmeweit et al., 1981; Pomper, 1975; Popkin, 1994; Sartori, 1982). De acordo com Campbell et al. (1960), a identificação partidária tem profundo impacto no comportamento eleitoral ao moldar atitudes e valores dos indivíduos em relação aos elementos da política, estabelecer referências para a estruturação do voto, formação de opiniões e atitudes políticas, fomentando vínculos estáveis entre cidadãos e partidos políticos. Outros estudos apontam, ainda, que os partidos políticos podem atuar como incentivo à participação eleitoral e fornecer informações que funcionam como atalhos que traduzem o mundo da política para o cidadão comum (Dalton, McAllister e Wattenberg, 2002; Popkin, 1994).

Apesar de o conceito de identidade partidária e partidarismo ter sofrido algumas modificações e classificações na literatura especializada (Gimenes et al., 2016), partidarismo é entendido como um vínculo estável e consistente entre partidos e eleitores, que estabelece um padrão de referências que influencia e conforma não só o comportamento eleitoral, como também a orientação política dos eleitores em relação a temas como democracia, avaliação do governo e da economia. O eleitor partidário é aquele que não apenas manifesta uma preferência baseada em orientações fundamentadas por variáveis conjunturais, mas compreende o mundo da política de forma mais ampla e se identifica com os valores e orientações fornecidos pelo partido, que oferece instrumentos para que o eleitor se posicione diante de determinados issues ou temas da agenda pública. O partidarismo funciona como importante fenômeno de estruturação e predição das escolhas eleitorais e políticas enraizadas, sendo fundamental para fomentar a legitimidade do sistema político. As fontes e o processo de formação do partidarismo têm uma longa tradição de pesquisa na ciência política, porém, isso não será retomado aqui, pois foge ao escopo deste artigo (Greene, 1999; Scarrow, 2000, 2015a; Dalton, McAllister e Wattenberg, 2002, 2003; Pedersen, Scarrow e Van Haute, 2015). 
Estudos mais recentes têm apontando para o declínio do partidarismo nas democracias mais longevas, detectando distintas configurações na relação entre partidos políticos e eleitores, observando reações e inovações nas estratégias adotadas pelos atores partidários diante da tendência geral de desalinhamento, tais como: multi-speed memberships e lite membership ${ }^{5}$ (Wattenberg, 2002; Scarrow, 2000, 2015a, 2015b; Norris, 2002; Dalton, McAllister e Wattenberg, 2003; Mair, 2003; Blais, 2013; Pedersen, Scarrow e Van Haute, 2015; Kosiara-Pedersen, Scarrow e Van Haute, 2015).

Três desdobramentos estão no centro do debate para o entendimento do fenômeno do desalinhamento partidário. Um diz respeito à avaliação de que essas transformações seriam uma crise da democracia representativa e o advento de uma nova formatação dos regimes democráticos, na qual os partidos não são o centro da formação da agenda pública e da organização das preferências eleitorais (Manin, 1995). Em uma linha mais extrema estão, ainda, as perspectivas que preveem a extinção dos partidos com as novas formas de ativismo e comunicação política (Whiteley, 2011).

O segundo, menos pessimista com relação ao diagnóstico, argumenta que o declínio dos níveis de identificação partidária teve como um de seus desdobramentos uma nova tipologia de partidos, o cartel party, mais centrada no Estado e no governo, com alto grau de esvaziamento de participação e incipiente envolvimento com o cidadão e os grupos sociais. A consequência principal dessa constatação não seria o desaparecimento das organizações, mas um remodelamento dessas instituições, que assumiriam, então, novas configurações (Katz e Mair, 1994; Norris, 2002; Schmitter, 2001; Mair, 2003).

O terceiro desdobramento trata mais especificamente das consequências da ascensão de novas formas de organização e ação política, de maneira a se destacarem modelos de democracia direta e novas tecnologias de comunicação que estariam se sobrepujando aos partidos (Deschouwer, 1996; Drucker, 1993; Lawson e Merkl, 1988; Torcal, Gunther e Montero, 2001). Outro resultado verificado é a ascensão de lideranças populistas (Baquero e Linhares, 2011; Lipow e Seyd, 1996) perante o vazio institucional.

Sob outra vertente situam-se análises que defendem a tese contrária ao diagnóstico do desalinhamento partidário. Os argumentos baseiam-se, por um lado, na

\footnotetext{
${ }^{5}$ De acordo com Scarrow, diante do distanciamento dos cidadãos e da relutância em participar da política partidária, os partidos criam alternativas como multi-speed memberships, isto é, a utilização de meios eletrônicos (Twitter, Facebook, lista de e-mails) para estabelecer novos e rápidos vínculos com eleitores (e potenciais "apoiadores"). Ainda que sejam formas reconhecidamente frágeis, esses laços podem ser altamente valiosos para mobilizar apoios, votos, divulgação de mensagens dos partidos e realização de atividades partidárias tradicionais. A autora afima que essa é uma ferramenta utilizada principalmente nos países em que há um acesso maior da população à internet. Ainda segundo Scarrow, os partidos têm buscado novas alternativas à filiação formal, como o registro de simpatizantes e filiações temporárias/experimentais. Essas opções têm uma variedade de formas e nomes, que a autora define como lite membership, na qual os partidos, a exemplo dos refrigerantes, prometem "o mesmo sabor a um custo menor" e se apresentam como se fossem marcas em disputa no mercado de eleitores. Sobre esses novos vínculos entre partidos e eleitores, ver Scarrow (2015a e 2015b).
} 
fragilidade das pesquisas de opinião pública para a aferição consistente do fenômeno em tela (Schmitt, 1989; Zelle, 1995) e, por outro, nos questionamentos quanto à associação direta entre os altos índices de volatilidade e fragmentação partidária e o declínio dos laços partidários (Bartolini e Mair, 1990). Os fenômenos observados não teriam uma relação de causa e efeito necessária, sendo apressado estabelecer um nexo entre ambos de forma consistente. Ainda nessa linha são apresentados argumentos segundo os quais é necessário observar com atenção se a queda da identificação partidária não está associada ao surgimento de um novo eleitor independente, mais escolarizado e com baixo nível de identificação partidária, ou à eclosão do antipartidarismo, um fenômeno de outra natureza (Aarts, Blais e Schmitt, 2013; Keith et al. 1992).

\section{Antipartidarismo e identidade partidária negativa}

É preciso traçar uma fronteira clara entre o que define e caracteriza um eleitor que manifesta algum nível de preferência partidária daquele que rejeita de forma peremptória todos os partidos ou alguma legenda específica. Consideramos fundamental a necessidade de diferenciar a não existência de preferência, a indiferença, a avaliação negativa em relação aos partidos, a rejeição a todos ou somente a um partido político.

Sem dúvida, a primeira manifestação trata de um vazio não ocupado, expressando, preponderantemente, a perspectiva de um eleitor que estaria predisposto a se alinhar, mas, no quadro de oferta partidária existente, não se sente vinculado ou representado por nenhuma organização. Esse cidadão tende a concordar que os partidos são importantes para um sistema democrático e sua estabilidade. Já a indiferença reflete um posicionamento mais associado à apatia em relação à política ou de desencanto advindo de sentimentos de desconfiança em relação aos partidos enquanto representantes dos interesses da sociedade (Mair, 2003; Baquero e Linhares, 2011). Por sua vez, o eleitor que avalia negativamente os partidos não manifesta própria e necessariamente uma rejeição às organizações partidárias em geral; sua postura pode indicar a manifestação de uma discordância ou avaliação negativa em relação à atuação partidária.

A literatura tem se esforçado nos últimos anos em construir de forma mais precisa tipologias referentes ao antipartidarismo e à identidade partidária negativa com a preocupação de desenvolver um instrumental capaz de observar as especificidades e variações que se manifestam nos fenômenos. Poguntke e Scarrow (1996, p. 259) definem, de forma apropriada, o antipartidarismo como um "desafeto em relação aos partidos, inclusive sua contestação". Os autores estabelecem gradações na manifestação desse fenômeno; em uma versão mais extremada estaria o antipartidarismo cultural, caracterizado por um ataque ao princípio segundo o qual a boa política necessita do papel intermediador e competitivo desempenhado pelos partidos políticos e pelas elites 
políticas, refletindo uma insatisfação sedimentada e difusa. Por outro lado, existiria também um antipartidarismo reativo, que utiliza argumentos mais moderados, aceita o papel mediador e de representação exercido pelos partidos políticos, no entanto, critica sua atuação em determinada conjuntura política. Ademais, os autores ainda chamam atenção para o uso de uma forma mais estendida e controversa do conceito de política antipartido para incluir ataques em relação a um partido específico, referindo-se a um contexto de proibição de partidos que supostamente ameacem a estabilidade democrática (1996, p. 258). Os autores destacam esse tipo, mas sem se ater conceitualmente ao constructo que diz respeito a essa manifestação, e não consideram a possibilidade de que a rejeição específica a somente um partido também poderia estar presente em relação a partidos que não refutam ou ameaçam a estabilidade democrática de um sistema político.

De forma semelhante a Poguntke e Scarrow (1996), Torcal, Gunther e Montero (2001) apontam duas formas de antipartidarismo com a preocupação de observar as distinções do fenômeno e também detectar seus impactos diferenciados no comportamento político. O antipartidarismo cultural é caracterizado por se fundamentar em uma existência de longo tempo, advinda de trajetórias políticas com regimes autoritários ou pseudodemocracias, instabilidade política e experiências com tradição de eleições não competitivas. Por sua vez, o antipartidarismo reativo está relacionado à insatisfação do cidadão em relação ao desempenho das elites partidárias e instituições.

É preciso também considerar que fatores específicos formatam sentimentos e características de antipartidarismos distintos. Escândalos, corrupção, avaliação de governo, mudanças sociais advindas de processos de modernização, reconfigurações na relação dos partidos com a sociedade são variáveis que impactam e interagem concomitantemente. A combinação de fatores estáticos sustentados por uma tradição cultural com partidos frágeis, pouco enraizados e afeitos a serem rejeitados com variáveis dinâmicas conjunturais impacta na construção do fenômeno que estamos analisando.

Um campo a ser desvendado e que ainda necessita de maior precisão conceitual é o que se refere à identidade partidária negativa, isto é, a decisão de nunca votar ou rejeitar radicalmente um determinado partido. Alguns autores têm apontado que a identidade partidária negativa é uma variável importante na estruturação da identidade política e no comportamento eleitoral (Rose e Mishler, 1998; Medeiros e Noël, 2014; Samuels e Zucco, 2015) ${ }^{6}$. Esse fenômeno tem sido pouco analisado e há uma agenda de pesquisa com muitas fronteiras a serem desbravadas, que vão desde esforços na construção da definição do conceito e da caracterização do fenômeno que possibilitem

\footnotetext{
${ }^{6}$ Agradecemos a Samuels e Zucco por nos possibilitar acesso ao trabalho apresentado na APSA (American Political Science Association) 2015.
} 
perspectivas de estudos comparados até a busca de fatores que o determinam, bem como quais os seus impactos no sistema político (Kestilä-Kekkonen, 2009; Ribeiro, Yan e Borba, 2011; Ignazi, 2014; Teixeira, Tsatsanis e Belchior, 2014).

Recentemente Medeiros e Noël (2014) afirmaram que as avaliações negativas têm sido largamente negligenciadas pelos cientistas políticos e constituem um lado esquecido do partidarismo e que ainda sabemos pouco sobre o tema. No entanto, argumentam que a identidade negativa pode revelar-se mais poderosa que a positiva, uma vez que as pessoas tendem a dar maior peso às más experiências que às boas. $A$ identidade partidária negativa e o compromisso de longo prazo de nunca votar em um determinado partido são elementos importantes para explicar o comportamento e os resultados eleitorais. Em um modelo de predição de intenção em quatro democracias anglo-saxônicas, os autores concluem que identidade partidária negativa aumenta consideravelmente o poder explicativo da equação, em suma é uma variável que desempenha um papel central.

Rose e Mishler (1998, p. 223) inovam ao propor uma classificação de tipos de partidarismos, possibilitando não somente observar as suas várias nuanças, mas também ofertar um instrumental que permita detectar de forma mais precisa um fenômeno que vem crescendo nas democracias contemporâneas. Sendo assim, são apresentados quatro tipos de partidarismo: a) "o partidarismo negativo", em que o eleitor afirma jamais votar em um determinado partido sem no entanto apresentar uma identidade partidária positiva; b) "o partidarismo fechado", que manifesta uma polarização nós $x$ eles, em que o eleitor apresenta simultaneamente uma identidade partidária positiva e negativa; c) o "partidarismo apático", que situa um eleitor sem identidades positivas ou negativas; d) o "partidarismo aberto", que caracteriza um eleitor comprometido com uma visão positiva de partido político e que não se identifica com um partido em que nunca votaria.

Com uma preocupação de observar de forma mais específica o antipetismo, Samuels e Zucco (2015), ao se debruçarem com as múltiplas facetas do antipartidarismo e suas fronteiras tênues, optam por fazer uma distinção entre os eleitores "antipartidários" e os "antipartidários puros", sendo esse último o correspondente ao conceito standard de "antipartidário", a saber, aqueles que rejeitam igualmente todos os partidos. Essa distinção ganha importância na medida em o conceito-padrão de "antipartidário" oblitera uma diferença fenomênica que eles pretendem investigar, que é o antipetismo em dois grupos, os que têm uma preferência partidária (partidários) e os que são "antipartidários puros". Por outro lado, e para complementar a distinção proposta, formulam uma distinção subjacente que ajuda a identificar os "antipetistas não puros" (expressão nossa), que possuem preferências partidárias específicas e indicam rejeição absoluta (em quem nunca votariam), e os "antipetistas puros", que são aqueles pertencentes ao grupo dos "antipartidários puros". 


\section{O eleitor brasileiro: preferência partidária e partidarismo}

Os estudos sobre a preferência partidária no período pós-transição democrática analisam as várias dimensões do fenômeno e uma delas se concentra na dinâmica e na evolução da preferência partidária, com a preocupação de avaliar as variáveis que causam o seu declínio. Alguns procuram compreender a lógica e a decisão do voto a partir da preferência partidária e a influência de variáveis socioeconômicas. Outros estudos intentam não somente avaliar a capacidade dos partidos em manter laços estáveis com o eleitorado, mas também detectar seu "conteúdo" associado a comportamentos, atitudes e ideologia. No que diz respeito ao debate sobre as causas dos baixos percentuais de preferência partidária, uma gama de variáveis são destacadas pelos investigadores, tais como especificidades do sistema político-partidário e da cultura política brasileira, afora a tendência geral, constatada em outros países, de desalinhamento partidário e arrefecimento dos vínculos entre os eleitores e as agremiações partidárias (Balbachewsky, 1992; Balbachewsky e Holzhacker, 2004; Carreirão, 2008; Carreirão e Kinzo, 2004; Kinzo, 1992, 2005; Lavareda, 1989; Silveira, 1998; Singer, 2000; Paiva, Braga e Pimentel Jr., 2007; Paiva e Tarouco, 2011; Veiga, 2007; Gimenes et al., 2016).

Singer (2000), analisando as duas primeiras eleições presidenciais após a redemocratização, conclui que a preferência partidária constitui uma variável estruturante da decisão do voto. A partir de um survey em que o entrevistado se autolocaliza na escala esquerda-direita, o autor chega a resultados que corroboram a tese da capacidade preditiva da preferência partidária nas razões do voto. Carreirão e Kinzo (2004) observam com resistência as conclusões de Singer (2000) e argumentam que os achados devem ser vistos com parcimônia, pois a predição da preferência partidária na decisão do voto se baseia somente no universo daqueles que manifestaram ter um partido preferido. Os autores (2004, p. 139) salientam que os coeficientes observados por Singer "não medem a relação direta entre preferência partidária e intenção de voto, mas a relação entre posicionamento ideológico dos partidos e a decisão do voto nos candidatos". Apesar das ressalvas, eles chegam à conclusão de que a preferência partidária não é uma variável a ser desconsiderada na formatação da decisão do voto (p. 160).

Também nesse sentido, Paiva, Braga e Pimentel Jr. (2007) ressaltam que, mesmo havendo diminuição da preferência partidária no período compreendido entre as eleições de 2002 e 2006, há um percentual que não pode ser desprezado. De acordo com os autores, "no Brasil existe uma parcela do eleitorado que é influenciada pelos partidos em sua decisão na hora de votar, o que demonstra que eles, em alguma medida, 
contribuem para estruturar o voto" ${ }^{\prime 7}$. Veiga (2007) chega a conclusões semelhantes no que diz respeito aos percentuais significativos de eleitores com preferência partidária e observa uma redução do nível de escolaridade destes ${ }^{8}$.

No entanto, há uma dimensão, demonstrada nos trabalhos de Veiga (2007), Martins Jr. (2009) e Venturi (2010), que reforça a tese da fragilidade e instabilidade dos laços estabelecidos com as legendas e indica não haver, de forma expressiva, o que na literatura se identifica como partidarismo. Veiga (2007), ao comparar os eleitores que manifestaram preferência partidária, detecta alterações significativas em curto espaço de tempo. Os eleitores com maior renda e que afirmaram ter preferência partidária se concentraram, em 2002, no PT e no PSDB e menos no PMDB (Partido do Movimento Democrático Brasileiro), com mudanças de perfil em 2006, quando aqueles que indicaram preferência pelo PT tinham renda menor; já em relação àquele eleitor que se identificou com o PMDB a tendência foi inversa. Martins Jr. (2009) reforça o perfil da instabilidade de laços partidários e aponta mudanças na composição social da base das preferências partidárias no Brasil. O autor observa, comparativamente, as bases socioeconômicas do voto do PT nas eleições presidenciais de 2002 e 2006 e diagnostica alterações substantivas:

Até 2002, o partido obtinha melhores chances entre os mais jovens, os mais escolarizados, os pertencentes à população economicamente ativa (PEA), na região Sul e nas capitais e regiões metropolitanas. Na eleição de 2006, essas chances invertem-se e o partido passa a obter melhores resultados entre os mais velhos, os menos escolarizados, os que estão fora da PEA, fora da região Sul e fora das capitais e regiões metropolitanas. Isso significa que ocorreu uma transformação profunda na base de apoio socioeconômico do partido quando este se tornou governo (Martins Jr., 2009, p. 90).

Venturi (2010), por sua vez, ao analisar especificamente a evolução da preferência partidária do PT desde os anos 1980, observa que alterações significativas foram apresentadas no perfil do eleitor que manifesta preferência pelo partido. A legenda ampliou sua base eleitoral e modificou sua configuração, antes concentrada em jovens, bem como alterou sua concentração regional e atingiu setores populares.

A partir dos resultados do Eseb 2010, Paiva e Tarouco (2011) apontam que PT, PSDB e PMDB concentram quase a totalidade das preferências dos entrevistados, com grande vantagem para o primeiro, com 58\%, enquanto PMDB e PSDB alcançam, respectivamente, $10,9 \%$ e $16,3 \%$. Todavia, chama a atenção o percentual bastante

\footnotetext{
7 Os autores destacam a análise nas perguntas "Algum partido político representa a sua maneira de pensar?", "Gosta de algum partido político?", mas não avaliam essas respostas na decisão de voto em si. ${ }^{8}$ Os estudos de Paiva, Braga e Pimentel Jr. (2007) e Veiga (2007) analisam os resultados do Eseb 2006.
} 
significativo daqueles que declaram não gostar de qualquer partido, mais da metade: $52,4 \%$.

Os dados analisados por Moisés e Carneiro (2014) também apontam para um cenário pouco promissor de adesão dos brasileiros aos partidos políticos. Entre 2006 e 2014, o percentual de entrevistados que afirmaram não confiar nos partidos políticos subiu de $36,6 \%$ para $46 \%$. Ainda de acordo com os autores, a grande maioria dos brasileiros, $77 \%$, afirmou não se sentir próximo a nenhum partido político. As tendências antes mencionadas corroboram com a tese de laços frágeis do eleitor com as agremiações partidárias. Elas não só indicam instabilidade nas preferências de alguns dos principais partidos brasileiros nas três últimas décadas como também a desconfiança do eleitorado em relação aos partidos, um ambiente aberto e receptivo para fomentar o antipartidarismo.

\section{Antipartidarismo e antipetismo no Brasil}

Há uma considerável produção acadêmica que aponta o distanciamento entre partidos políticos e eleitores no Brasil. Em geral, os estudos destacam os baixos níveis de preferência partidária e/ou de confiança nos partidos políticos (Balbachevsky, 1992; Balbachevsky e Holzhacker, 2004; Baquero e Linhares, 2011; Kinzo, 2005; Mainwaring, 1999; Moisés e Carneiro, 2014; Paiva, Braga e Pimentel Jr., 2007; Samuels, 2006; Veiga, 2007).

Os dados do Eseb (ver Tabela 1) permitem afirmar que mais da metade dos brasileiros não se sente representada pelos partidos políticos e mostram que, com exceção de 2010, essa percepção é crescente, chegando a 71,9\% em 2014. A ausência de laços partidários caminha na mesma direção, salvo em 2010 (47,7\%), haja vista que pelo menos a metade não se sente próxima ou afirma ter algum "gosto" pelos partidos, chegando a $71 \%$ em 2014.

Tabela 1

Partidos e eleitores no Brasil (\%) ${ }^{9}$

\begin{tabular}{|l|c|c|c|c|c|c|c|c|c|}
\hline \multicolumn{4}{|c|}{$\begin{array}{c}\text { Algum partido político representa sua } \\
\text { maneira de pensar? }\end{array}$} & \multicolumn{4}{c|}{ Gosta de algum partido político mais que } \\
dos outros?
\end{tabular}

Fonte: Eseb 2002, 2006, 2010 e 2014.

\footnotetext{
9 Os entrevistados responderam às seguintes perguntas (em todas as edições do Eseb): "Algum partido político representa a sua maneira de pensar?", "Existe algum partido político que goste mais que os outros?". A primeira mensurou a preferência partidária (coluna à esquerda) e a segunda, o "gosto" partidário (coluna à direita).
} 
As quatro ondas do Eseb indicam que existe terreno fértil para a proliferação do antipartidarismo e partidarismo negativo no país, fenômeno que não tem sido analisado de forma mais detalhada ou exaustiva pela literatura, que, em geral, destaca apenas as baixas taxas de preferência partidária e o distanciamento entre partidos e eleitorado.

Telles $^{10}$ (2015a, 2015b), ao investigar o tema, afirma que pesquisas de opinião pública mais recentes têm demonstrado uma atitude crítica dos brasileiros em relação à função e à atuação dos partidos políticos, resultando em insatisfação com a política. $O$ resultado é a emergência de um antipartidarismo reativo, isto é, um gap entre a inconsistência das promessas dos partidos políticos e a grande expectativa dos cidadãos em relação à eficácia das instituições e das elites partidárias.

Embora o PT e/ou o petismo, em suas diferentes dimensões, tenha sido objeto de um número expressivo de estudos desde a sua fundação em 1980 (Amaral, 2010; César, 2002; Keck, 1992; Hunter, 2007; Lacerda, 2002; Meneguello, 1989; Ribeiro, 2009; Samuels, 2004, 2008; Samuels e Zucco, 2014; Venturi, 2010; Villa et al., 2009), ainda há uma lacuna na literatura em relação ao eleitor que rejeita o partido, o antipetista.

A existência de um sentimento antipetista se torna ainda mais interessante como tema de investigação se considerarmos que, em todas as edições do Eseb $(2002,2006$, 2010), o partido aparece em primeiro lugar na escala de sentimentos partidários, em termos de apelo efetivo positivo (Braga e Pimentel Jr., 2011; Paiva, Braga e Pimentel Jr., 2007; Paiva e Tarouco, 2011). Conforme afirmam Braga e Pimentel Jr. (2011), nas questões que visavam medir o nível do partidarismo no Brasil, o PT alcançou níveis mais expressivos que as demais legendas (com destaque para aquelas mais conhecidas PSDB, PMDB e DEM (Democratas)), o mesmo fato pôde ser verificado em 2014. Contudo, uma ressalva a ser feita é que os níveis de preferência partidária em geral são baixos, como pudemos constatar na Tabela 1.

Perfil dos eleitores antipetista e antipartidário

Ao analisarmos os dados da pergunta que procura medir o nível de partidarismo ou antipartidarismo em relação a alguns partidos políticos ${ }^{11}$, há duas informações que sobressaem: a primeira, conforme já adiantamos na seção "Antipartidarismo e antipetismo no Brasil", é a de que o PT detém o maior índice de partidarismo $(13,5 \%)$, muito superior ao partido que vem em segundo lugar, PSDB, com 5,1\%. A segunda se

\footnotetext{
${ }^{10}$ Agradecemos a Helcimara Telles pelas contribuições na discussão da definição do eleitor antipetista por nós investigado.

${ }^{11}$ Os entrevistados receberam uma cartela com a lista dos partidos e responderam à seguinte pergunta: "Agora gostaria de saber com mais detalhes o que o(a) sr(a). pensa sobre alguns partidos políticos. Por favor, para cada partido que eu citar, gostaria que atribuísse uma nota de 0 a 10 , sendo que 0 significa que o(a) sr(a). não gosta de jeito nenhum do partido e 10 que o(a) sr(a). gosta muito. Se eu falar o nome de um partido que o(a) sr(a). não conhece, apenas diga que não o conhece".
} 
refere ao fato de o percentual de rejeição ao PT não ser uma exclusividade dessa legenda, ao contrário, é muito significativo que o percentual de rejeição manifestado em relação ao partido também se apresente de forma muito semelhante em relação aos outros partidos importantes no cenário político brasileiro. Ou seja, parte significativa dos entrevistados apresentou, concomitantemente, rejeição a vários partidos. Isso sem dúvida diz respeito ao fenômeno do antipartidarismo.

Tabela 2

Rejeição e identificação em relação aos principais partidos

\begin{tabular}{|l|c|c|c|c|c|c|}
\hline \multirow{2}{*}{} & \multicolumn{2}{|c|}{$\begin{array}{c}\text { Não gosta de } \\
\text { jeito nenhum } \\
\text { (00) }\end{array}$} & \multicolumn{2}{c|}{$\begin{array}{c}\text { Gosta muito } \\
\mathbf{( 1 0 )}\end{array}$} & \multicolumn{2}{c|}{ Não conhece } \\
\cline { 2 - 7 } & $\mathbf{N}$ & $\mathbf{\%}$ & $\mathbf{N}$ & $\mathbf{\%}$ & $\mathbf{N}$ & \% \\
\hline DEM & 498 & 19,9 & 25 & 1,0 & 729 & 29,1 \\
\hline PSC & 500 & 19,9 & 19 & 0,8 & 752 & 30,0 \\
\hline PSOL & 493 & 19,7 & 27 & 1,1 & 537 & 21,4 \\
\hline PR & 487 & 19,4 & 17 & 0,7 & 778 & 31,1 \\
\hline PT & 482 & $\mathbf{1 9 , 2}$ & 338 & $\mathbf{1 3 , 5}$ & 97 & 3,9 \\
\hline PSD & 477 & 19,0 & 27 & 1,1 & 711 & 28,4 \\
\hline PTB & 472 & 18,8 & 30 & 1,2 & 573 & 22,9 \\
\hline PDT & 467 & 18,7 & 31 & 1,2 & 510 & 20,4 \\
\hline PV & 451 & 18,0 & 35 & 1,4 & 515 & 20,6 \\
\hline PMDB & 446 & 17,8 & 83 & 3,3 & 225 & 9,0 \\
\hline PSB & 444 & 17,7 & 32 & 1,3 & 601 & 24,0 \\
\hline PSDB & 438 & $\mathbf{1 7 , 5}$ & 128 & $\mathbf{5 , 1}$ & 260 & 10,4 \\
\hline
\end{tabular}

Fonte: Elaboração própria com base no Eseb 2014. $\mathrm{N}=2506$.

Nota: As linhas não somam $100 \%$ porque as respostas de notas de 1 a 9 , NS e NR foram omitidas.

Com base nesses dados poderíamos argumentar, apressadamente, que, tendo em vista serem os percentuais de rejeição de todos os partidos muito parecidos, não existiria um antipetismo, mas um antipartidarismo por parte dos eleitores brasileiros. Ocorre que, ao analisarmos a amostra de eleitores que responderam não gostar de jeito nenhum do PT $(\mathrm{N}=482)^{12}$ em relação aos demais partidos, vemos que boa parte dela (de $50 \%$ a $61,6 \%$, conforme o partido - ver Tabela 3) também rejeita as outras legendas, mas resta uma parcela que rejeita exclusivamente o PT. Portanto, existe um antipartidarismo generalizado, mas há também uma rejeição voltada especificamente ao PT, o antipetismo, já que uma parte considerável dos eleitores respondeu não gostar de jeito nenhum apenas desse partido.

\footnotetext{
12 Neste artigo, estamos interessadas naquele eleitor que rejeita radicalmente o PT (que Ihe deu nota 0), por isso não agregamos os eleitores que atribuíram notas de 1 a 3 - que representariam uma variação entre maior e menor rejeição ao partido - à análise.
} 


\section{Tabela 3 \\ Rejeição e identificação do eleitor antipetista em relação aos demais partidos}

\begin{tabular}{|l|c|c|c|c|c|c|}
\hline & \multicolumn{2}{|c|}{$\begin{array}{c}\text { Não gosta de } \\
\text { jeito nenhum } \\
\text { (00) }\end{array}$} & \multicolumn{2}{c|}{$\begin{array}{c}\text { Gosta muito } \\
(10)\end{array}$} & \multicolumn{2}{c|}{ Não conhece } \\
\cline { 2 - 7 } & N & \% & N & \% & N & \% \\
\hline PSOL & 297 & 61,6 & 4 & 0,8 & 51 & 10,6 \\
\hline PTB & 296 & 61,4 & 4 & 0,8 & 56 & 11,6 \\
\hline PDT & 291 & 60,5 & 3 & 0,6 & 49 & 10,2 \\
\hline PSC & 284 & 59,0 & 2 & 0,4 & 87 & 18,1 \\
\hline PMDB & 283 & 58.8 & 17 & 3,5 & 11 & 2,3 \\
\hline PSB & 282 & 58,6 & 6 & 1,2 & 59 & 12,3 \\
\hline DEM & 281 & 58,5 & 4 & 0,8 & 83 & 17,3 \\
\hline PV & 282 & 58,4 & 5 & 1,0 & 38 & 7,9 \\
\hline PR & 281 & 58,3 & 1 & 0,2 & 93 & 19,3 \\
\hline PSD & 278 & 57,8 & 4 & 0,8 & 77 & 16,0 \\
\hline PSDB & 241 & 50,0 & 48 & 10,0 & 9 & 1,9 \\
\hline
\end{tabular}

Fonte: Elaboração própria com base no Eseb 2014. N = 482.

Nota: As linhas não somam $100 \%$ porque as respostas de notas 1 a 9, NS e NR foram omitidas.

Conforme ficou evidente pela discussão acima, a amostra formada pelos eleitores que responderam não gostar de jeito nenhum do PT ( $N=482)$, atribuindo-lhe nota 0 , não é composta exclusivamente por antipetistas, mas também por aqueles que rejeitam todos os partidos indistintamente, os antipartidários. Considerando que o nosso interesse é, especificamente, o eleitor antipetista, optamos por isolá-lo do antipartidário. Para tanto, dividimos a amostra de 482 respondentes que atribuíram nota 0 ao PT através da diferenciação das respostas e, por esse intermédio, criamos outras duas variáveis, com base nos seguintes critérios: (a) eleitor antipetista - aquele que atribuiu nota 0 somente ao PT e notas diferentes de 0 aos outros partidos (ou ainda, respondeu não conhecer os demais partidos ou não saber que nota conceder-lhes ou preferiu não responder sobre eles, mas para o PT conferiu nota 0); (b) eleitor antipartidário - aquele que atribuiu nota 0 a todos os partidos (ou que deu nota 0 ao PT e a alguns partidos e, para os outros, respondeu não conhecê-los ou não saber que nota atribuir-lhes ou preferiu não responder sobre eles $)^{13}$. Com isso, obtivemos a variável denominada "antipetistas", com

13 Eleitor antipartidário que atribuiu 0 ao PT e a alguns partidos e 96 (não conhece), 98 (não sabe) e 99 (não respondeu) aos demais.

Ex::
\begin{tabular}{|l|l|l|l|l|l|l|l|l|l|l|l|}
\hline Q9a: & Qb: & Q9c: & Q9d: & Q9e: & Q9f: & Q9g: & Q9h: & Q9i: & Q9j: & Q9k: & Q91: \\
PT & PMDB & PDT & PTB & PSDB & PV & DEM & PSOL & PSB & PR & PSC & PSD \\
\hline 0 & 0 & 0 & 0 & 0 & 0 & 98 & 96 & 0 & 96 & 96 & 96 \\
\hline
\end{tabular}


$\mathrm{N}=268$, e a variável "antipartidários", com $\mathrm{N}=214$. O refinamento das respostas mostrou-se uma opção acertada, pois, conforme demonstramos na sequência do trabalho, antipetistas e antipartidários são dois grupos diferentes demograficamente. Consequentemente, se tivéssemos classificado todos os 482 respondentes que atribuíram nota 0 ao PT como sendo antipetistas e, por conta disso, os tivéssemos considerado sujeitos semelhantes entre si, visto serem pertencentes a uma mesma categoria de resposta, teríamos incluído muito mais erros na análise do perfil do antipetista.

Para traçar o perfil do antipetista, selecionamos variáveis sociodemográficas e aquelas que permitiam mensurar, direta ou indiretamente, a preferência partidária do eleitor e, ainda, aquelas relativas à avaliação do governo e à avaliação retrospectiva e prospectiva da economia. Um grande número de questões da pesquisa Eseb 2014 foi testado, porém, apresentamos, na continuidade do trabalho, apenas aquelas que tiveram significância estatística.

Começando pelas variáveis sociodemográficas, a maioria dos antipetistas se identifica como branco (52\%), apresentando uma diferença significativa quando comparamos com a amostra total pesquisada ( $\mathrm{N}=2.506$, branco $39,1 \%)$. Já entre os antipartidários, a maioria se identifica como preto ou pardo $(60,3 \%)$, não se distinguindo de forma significativa do padrão da amostra total pesquisada $(57,8 \%)$.

Os antipetistas têm maior escolarização, pois a maioria deles $(58,2 \%)$ possui pelo menos ensino médio completo. Destaca-se o fato de haver muito mais antipetistas com grau elevado de escolaridade (ensino superior completo, pós-graduação ou mais) do que entre o total de eleitores entrevistados. Entre os antipartidários, a maioria $(54,8 \%)$ possui menor escolaridade, no máximo ensino médio incompleto.

Tabela 4

Escolaridade dos eleitores antipetistas e antipartidários

\begin{tabular}{|c|c|c|c|c|c|c|}
\hline & \multicolumn{2}{|c|}{ Antipetistas } & \multicolumn{2}{|c|}{ Antipartidários } & \multicolumn{2}{|c|}{$\begin{array}{c}\text { Total de } \\
\text { entrevistados }\end{array}$} \\
\hline & $\mathbf{N}$ & $\%$ & $\mathbf{N}$ & $\%$ & $\mathbf{N}$ & $\%$ \\
\hline Analfabeto / Nunca frequentou a escola & 6 & 2,1 & 10 & 4,8 & 106 & 4,2 \\
\hline Ensino fundamental incompleto & 54 & 20,2 & 64 & 29,9 & 787 & 31,4 \\
\hline Ensino fundamental completo & 29 & 10,7 & 27 & 12,5 & 303 & 12,1 \\
\hline Ensino médio incompleto & 24 & 8,8 & 16 & 7,6 & 203 & 8,1 \\
\hline Ensino médio completo & 81 & 30,3 & 57 & 26,6 & 675 & 26,9 \\
\hline $\begin{array}{l}\text { Ensino superior incompleto ou especialização (técnico } \\
\text { após o ensino médio) }\end{array}$ & 28 & 10,5 & 23 & 10,8 & 203 & 8,1 \\
\hline Ensino superior completo ou pós-graduação ou mais & 47 & 17,4 & 17 & 7,7 & 230 & 9,1 \\
\hline Total & 268 & 100,0 & 214 & 100,0 & 2506 & 100,0 \\
\hline
\end{tabular}

Fonte: Eseb, 2014.

No que diz respeito à renda familiar mensal, novamente, os antipetistas diferenciam-se da amostra total de entrevistados e dos antipartidários, pois estão mais concentrados nos segmentos de renda mais elevados (acima de cinco salários mínimos). 
Já $68,6 \%$ dos antipartidários possuem renda familiar mensal de até cinco salários mínimos.

Tabela 5

Renda familiar mensal de antipetistas e antipartidários

\begin{tabular}{|c|c|c|c|c|c|c|}
\hline & \multicolumn{2}{|c|}{ Antipetistas } & \multicolumn{2}{|c|}{ Antipartidários } & \multicolumn{2}{|c|}{$\begin{array}{c}\text { Total de } \\
\text { entrevistados }\end{array}$} \\
\hline & $\mathbf{N}$ & $\%$ & $\mathbf{N}$ & $\%$ & $\mathbf{N}$ & $\%$ \\
\hline $\begin{array}{l}\text { Até R\$ 724,00 (até } 1 \text { salário mínimo - } \\
\text { SM) }\end{array}$ & 20 & 7,5 & 21 & 10,0 & 277 & 11,1 \\
\hline $\begin{array}{l}\text { De } R \$ 725,00 \text { até } R \$ 1.448,00 \text { (mais de } \\
1 \text { até } 2 \text { SM) }\end{array}$ & 51 & 19,0 & 54 & 25,3 & 601 & 24,0 \\
\hline $\begin{array}{l}\text { De } R \$ 1.449,00 \text { até } R \$ 3.620,00 \text { (mais } \\
\text { de } 2 \text { até } 5 \text { SM) }\end{array}$ & 103 & 38,3 & 71 & 33,3 & 998 & 39,8 \\
\hline $\begin{array}{l}\text { De } R \$ 3.621,00 \text { até } R \$ 7.240,00 \text { (mais } \\
\text { de } 5 \text { até } 10 \text { SM) }\end{array}$ & 44 & 16,4 & 21 & 9,9 & 249 & 9.9 \\
\hline $\begin{array}{l}\text { De } R \$ 7.241,00 \text { a } R \$ 10.860,00 \text { (mais de } \\
10 \text { até } 15 \mathrm{SM} \text { ) }\end{array}$ & 12 & 4,5 & 6 & 2,9 & 39 & 1,6 \\
\hline $\begin{array}{l}\text { A partir de } \mathrm{R} \$ 10.861,00 \text { (mais de } 15 \\
\mathrm{SM} \text { ) }\end{array}$ & 9 & 3,4 & 1 & 0,6 & 38 & 1,5 \\
\hline $\mathrm{NS}, \mathrm{NR}$ e NSA & 29 & 10,8 & 38 & 18,0 & 304 & 12,1 \\
\hline Total & 268 & 100,0 & 214 & 100,0 & 2506 & 100,0 \\
\hline
\end{tabular}

Fonte: Eseb, 2014.

Também há uma sobrerrepresentação dos antipetistas nas classes sociais "mais alta" $(0,4 \%)$, "média alta" $(8,2 \%)$ e "média média" $(34,5 \%)$ do que na amostra total, cujos percentuais para essas classes são, respectivamente, 0,2\%, 3,5\% e 25\%. Os dados do Eseb 2014 sobre o antipetista confirmam perfis semelhantes encontrados posteriormente por Telles (2015b) nos manifestantes que protestaram contra o governo em 2015.

Com relação à ocupação, chama a atenção o fato de que a maior parcela de antipetistas se classifica como patrão $(8,6 \%)$, diferenciando-se da amostra geral de eleitores (4,8\%); o índice cai para menos de $1 \%$ entre os antipartidários $(0,7 \%)$. Ademais, os antipetistas são mais numerosos $(40,6 \%)$ do que os antipartidários $(35,7 \%)$ na categoria empregado e estes possuem maior quantidade de eleitores trabalhando por conta própria $(41,1 \%)$ do que os antipetistas $(28,4 \%)$. Enquanto entre os antipetistas há maior percentual de patrões do que na amostra total, entre os antipartidários há menor percentagem de empregados do que entre todos os entrevistados e maior índice de pessoas trabalhando como autônomas do que entre os respondentes da pesquisa, como já foi observado.

Outro dado relevante é que os antipetistas estão concentrados na região Sudeste, principalmente no estado de São Paulo, conforme demonstra a Tabela 6: 
Tabela 6

Localização geográfica do antipetista e do antipartidário

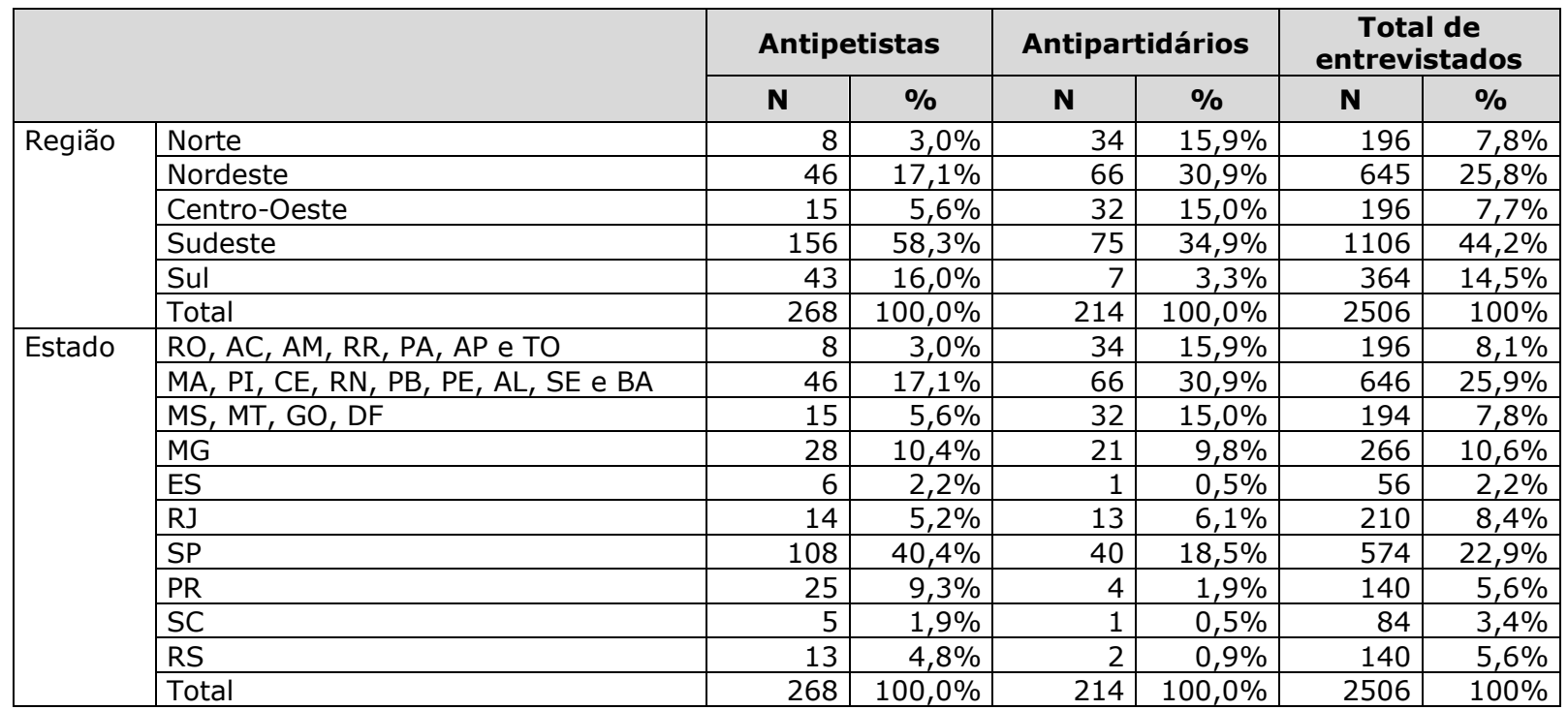

Fonte: Eseb, 2014.

Pode-se destacar, então, a partir dos resultados apresentados, que o eleitor antipetista é predominantemente de cor branca, possui maior escolaridade e está em número superior ao dos demais eleitores nos estratos de maior renda familiar mensal, de camadas sociais mais elevadas e entre os empregadores. O antipetismo é um fenômeno, majoritariamente, da região Sudeste, principalmente paulista. Apesar de serem a região e o estado mais populosos do Brasil, mesmo assim o antipetismo tem maior peso nessa região do que ela própria em relação ao restante do Brasil.

Agora passamos a analisar as variáveis de medição direta e indireta da identificação partidária, ou preferência partidária. Conforme adiantamos na seção "Antipartidarismo e antipetismo no Brasil", em nosso país, em consonância com o restante do mundo, é baixo o nível de identificação partidária, fato corroborado pela grande quantidade de pessoas que responderam não existir algum partido político do qual goste mais, sendo esse índice de $57,1 \%$ entre os antipetistas e de $88,9 \%$ entre os antipartidários. No entanto, dos $41,5 \%$ dos antipetistas que dizem gostar mais de um determinado partido do que dos outros, 58,4\% apontaram o PSDB como o de sua preferência e outros 19,9\% indicaram o PMDB. Além disso, quando perguntados se gostam ou não do $\mathrm{PSDB}^{14}$, os antipetistas, em sua maioria $(50,7 \%)$, atribuem-lhe notas

${ }^{14}$ Os entrevistados receberam uma cartela com a lista dos partidos políticos e responderam à pergunta: "Agora gostaria de saber com mais detalhes o que o(a) $\operatorname{sr}(a)$. pensa sobre alguns partidos políticos. Por favor, para cada partido que eu citar, gostaria que atribuísse uma nota de 0 a 10 , sendo que 0 significa 
positivas (de 7 a 10), sendo que 17,9\% destes dizem gostar muito desse partido (nota = 10). Em contrapartida, dentre os pouquíssimos eleitores antipartidários que afirmaram ter algum partido do qual goste mais $(6,5 \%)$, a maioria $(3,6 \%)$ indicou ser o PT esse partido.

Outro dado relevante que permite captar a preferência partidária do eleitor antipetista pelo PSDB é a sua aproximação ideológica com esse partido. Quando perguntados como se autolocalizam no espectro ideológico esquerda-direita, 44,6\% definem-se como de centro-direita ou direita. Além disso, 37,9\% localizam o PSDB na posição ideológica de centro-direita ou direita e 50,7\% consideram o PT como de esquerda ou de centro-esquerda. Portanto, pode-se dizer que o antipetista tem uma identificação ideológica com o PSDB e um antagonismo ideológico com o PT, segundo demonstra a Tabela 7. Esses dados apontam o que tem sido destacado em pesquisas posteriores aos protestos ocorridos em 2015 e 2016, uma polarização PT versus PSDB (Tatagiba, Trindade e Chaves Teixeira, 2015), que começou a partir das disputas das eleições nacionais protagonizadas por esses dois partidos desde 1994, disputa que foi ainda mais acirrada nas eleições presidenciais de 2014.

que o(a) sr(a). não gosta de jeito nenhum do partido e 10 que o(a) sr(a). gosta muito. Se eu falar o nome de um partido que o(a) sr(a). não conhece, apenas diga que não o conhece". 
Tabela 7

Autolocalização no espectro ideológico e localização dos partidos

\begin{tabular}{|c|c|c|c|c|c|}
\hline & \multicolumn{2}{|c|}{ Antipetistas } & \multicolumn{2}{|c|}{ Antipartidários } \\
\hline & & $\mathbf{N}$ & $\%$ & $\mathbf{N}$ & $\%$ \\
\hline \multirow{7}{*}{$\begin{array}{l}\text { Autolocalização } \\
\text { Esquerda ou Direita }\end{array}$} & 0 - Esquerda & 13 & 4,7 & 5 & 2,3 \\
\hline & 1-4 - Centro-esquerda & 12 & 4,4 & 15 & 7,2 \\
\hline & 5 - Centro & 30 & 11,1 & 14 & 6,6 \\
\hline & 6-9 - Centro-direita & 71 & 26,4 & 24 & 11,1 \\
\hline & 10 - Direita & 49 & 18,2 & 16 & 7,3 \\
\hline & $\begin{array}{l}\text { Não sabe o que é } \\
\text { esquerda e direita, não } \\
\text { sabe ou não respondeu }\end{array}$ & 94 & 35,2 & 140 & 65,4 \\
\hline & Total & 268 & 100,0 & 214 & 100,0 \\
\hline \multirow{7}{*}{$\begin{array}{l}\text { Localização - Esquerda } \\
\text { ou Direita: PSDB }\end{array}$} & 0 - Esquerda & 14 & 5,3 & 19 & 9,0 \\
\hline & 1-4 - Centro-esquerda & 20 & 7,5 & 14 & 6,5 \\
\hline & 5 - Centro & 21 & 7,7 & 3 & 1,6 \\
\hline & 6-9 - Centro-direita & 66 & 24,7 & 12 & 5,7 \\
\hline & 10 - Direita & 36 & 13,2 & 14 & 6,6 \\
\hline & $\begin{array}{l}\text { Não conhece, não sabe, } \\
\text { não respondeu ou não } \\
\text { se aplica }\end{array}$ & 111 & 41,5 & 151 & 70,5 \\
\hline & Total & 268 & 100,0 & 214 & 100,0 \\
\hline \multirow{7}{*}{$\begin{array}{l}\text { Localização - Esquerda } \\
\text { ou Direita: PT }\end{array}$} & 0 - Esquerda & 107 & 39,7 & 24 & 11,3 \\
\hline & 1-4 - Centro-esquerda & 29 & 11,0 & 15 & 6,9 \\
\hline & 5 - Centro & 8 & 2,9 & 6 & 2,8 \\
\hline & 6-9 - Centro-direita & 8 & 2,8 & 6 & 2,7 \\
\hline & 10 - Direita & 10 & 3,9 & 14 & 6,7 \\
\hline & $\begin{array}{l}\text { Não conhece, não sabe, } \\
\text { não respondeu ou não } \\
\text { se aplica }\end{array}$ & 107 & 39,7 & 149 & 69,6 \\
\hline & Total & 268 & 100,0 & 214 & 100,0 \\
\hline
\end{tabular}

Fonte: Eseb, 2014.

Não por acaso, os candidatos do PSDB nas eleições presidenciais de 2010 e de 2014 foram a escolha majoritária do eleitor antipetista, como se verifica na Tabela 8: 


\section{Tabela 8 \\ Voto dos antipetistas e dos antipartidários nas eleições presidenciais de 2010 e 2014}

\begin{tabular}{|c|c|c|c|c|c|}
\hline & & \multicolumn{2}{|c|}{ Antipetistas } & \multicolumn{2}{|c|}{ Antipartidários } \\
\hline & & $\mathbf{N}$ & $\%$ & $\mathbf{N}$ & $\%$ \\
\hline \multirow{4}{*}{$\begin{array}{l}\text { Candidato em quem votou } \\
\text { no } 1^{0} \text { turno da eleição } \\
\text { presidencial de } 2014\end{array}$} & Aécio Neves - PSDB & 174 & 74,4 & 41 & 28,1 \\
\hline & Dilma Rousseff - PT & 15 & 6,4 & 76 & 52,2 \\
\hline & Outro candidato & 45 & 19,2 & 29 & 19,7 \\
\hline & Total & 234 & 100,0 & 146 & 100,0 \\
\hline \multirow{3}{*}{$\begin{array}{l}\text { Candidato em quem votou } \\
\text { no } 20 \text { turno da eleição } \\
\text { presidencial de } 2014\end{array}$} & Aécio Neves - PSDB & 216 & 92,1 & 63 & 41,8 \\
\hline & Dilma Rousseff - PT & 19 & 7,9 & 88 & 58,2 \\
\hline & Total & 234 & 100,0 & 152 & 100,0 \\
\hline \multirow{4}{*}{$\begin{array}{l}\text { Candidato em quem votou } \\
\text { no } 1^{0} \text { turno da eleição } \\
\text { presidencial de } 2010\end{array}$} & Dilma Rousseff - PT & 55 & 28,6 & 78 & 71,9 \\
\hline & José Serra - PSDB & 103 & 53,0 & 19 & 17,8 \\
\hline & Outro candidato & 36 & 18,4 & 11 & 10,2 \\
\hline & Total & 194 & 100,0 & 108 & 100,0 \\
\hline \multirow{4}{*}{$\begin{array}{l}\text { Candidato em quem votou } \\
\text { no } 20 \text { turno da eleição } \\
\text { presidencial de } 2010\end{array}$} & Dilma Rousseff - PT & 60 & 22,5 & 81 & 38,0 \\
\hline & José Serra - PSDB & 138 & 51,5 & 27 & 12,7 \\
\hline & $\begin{array}{l}\text { Branco, Nulo, Não } \\
\text { Sabe, Não Respondeu } \\
\text { ou Não se Aplica }\end{array}$ & 70 & 26,0 & 105 & 49,2 \\
\hline & Total & 268 & 100,0 & 214 & 100,0 \\
\hline
\end{tabular}

Fonte: Eseb, 2014.

Também não é mera coincidência que, ao serem perguntados sobre o quanto gostam de alguns políticos ${ }^{15}$, os antipetistas não tenham demonstrado muito apreço pelos políticos em geral, mas, com relação ao senador Aécio Neves (PSDB), 73,6\% declararam gostar ou gostar muito (notas de 7 a 10) e apenas 6,1\% disseram não gostar de jeito nenhum. Entre os antipartidários ocorre o inverso: $41 \%$ responderam não gostar de jeito nenhum e somente 19,3\% afirmaram gostar ou gostar muito. Em relação a Dilma Rousseff (PT), a maioria dos antipetistas $(83,8 \%)$ respondeu não gostar de jeito nenhum ou não gostar (notas de 0 a 3 ) dela, sendo que a maior parcela $(63,6 \%$ ) a rejeita completamente. Novamente, há um posicionamento distinto dos antipartidários: esse índice de total rejeição a Dilma Rousseff (PT) cai para 30,6\%, enquanto aqueles que gostam ou gostam muito dela (notas de 7 a 10) correspondem a 35,3\%. No tocante aos demais políticos, os antipartidários compartilham com os antipetistas a rejeição generalizada a eles. A rejeição a um partido pode dar-se não apenas em decorrência da preferência partidária ou da aproximação ideológica, mas também pelas avaliações negativas do desempenho do governo e da conjuntura econômica. Por esse prisma, torna-se relevante analisar como antipetistas e antipartidários avaliam o governo do PT no Executivo federal e a economia sob sua administração.

15 " [...] Gostaria que o(a) sr(a). me dissesse o quanto gosta de alguns políticos que vou mencionar. Quero lembrar que 0 significa que $o(a)$ sr(a). não gosta de jeito nenhum do político que vou mencionar e 10 que o(a) sr (a). gosta muito. [...]". 
Os antipetistas têm uma visão negativa da economia: 53,5\% consideram que a situação econômica do país piorou em comparação com os últimos 12 meses e 51,6\% creem ser muito provável ou provável que a renda familiar de seu domicílio seja reduzida nos 12 meses futuros. Em contrapartida, os eleitores antipartidários avaliam a economia do país de modo mais positivo: para a maioria deles $(68,3 \%)$, a situação econômica do país melhorou ou continuou igual, comparada aos 12 meses pregressos, e $42,1 \%$ deles não acreditam que sua renda será reduzida, contra apenas $33,8 \%$ que pensam ser provável ou muito improvável que ela sofra decréscimo.

Conforme demonstra a Tabela 9, na sequência, os antipetistas, maciçamente, têm uma avaliação negativa do governo da presidente Dilma Rousseff (PT). Impressionam as diferenças entre antipetistas e antipartidários em relação à avaliação do governo, visto que estes apresentam dados mais positivos. Antes de tirarmos qualquer conclusão a partir dessa variável, é preciso olhar a avaliação negativa do governo do PT com parcimônia, pois pode haver uma relação entre variáveis intervenientes. Isso significa dizer que, com as informações disponíveis, não é possível afirmar com segurança que o antipetista rejeita o PT porque está insatisfeito com o desempenho do governo ou porque é antagônico, ideológica ou pragmaticamente, a esse governo.

Tabela 9

Avaliação do governo Dilma Rousseff nos últimos quatro anos

\begin{tabular}{||l|r|r|r|r|}
\hline \multirow{2}{*}{} & \multicolumn{2}{|c|}{ Antipetistas } & \multicolumn{2}{c|}{ Antipartidários } \\
\cline { 2 - 5 } & $\mathrm{N}$ & \multicolumn{1}{c|}{$\%$} & $\mathrm{~N}$ & \multicolumn{1}{c|}{} \\
\hline Ótimo ou Bom & 22 & 8,2 & 77 & 36,1 \\
\hline Regular & 54 & 20,0 & 73 & 34,3 \\
\hline Ruim ou Péssimo & 190 & 70,9 & 61 & 28,4 \\
\hline Não Sabe, Não Respondeu ou Não se Aplica & 3 & 0,9 & 3 & 1,2 \\
\hline Total & 268 & 100,0 & 214 & 100,0 \\
\hline
\end{tabular}

Fonte: Eseb, 2014.

Nesta subseção, além de descrevermos o perfil do eleitor antipetista, ainda demonstramos que o grupo de eleitores que responderam não gostar de jeito nenhum do PT são dois sujeitos distintos: os antipetistas e os antipartidários em geral diferenciam-se em muitas das variáveis analisadas. Na sequência, são testadas as nossas duas hipóteses, a partir da análise das variáveis avaliação do governo Dilma e gosta do PSDB, a fim de examinar os seus impactos sobre a probabilidade de o respondente ser identificado como antipetista. Também são explorados os efeitos de algumas variáveis sociodemográficas sobre a probabilidade de o eleitor ser ou não ser antipetista. 


\section{Determinantes do antipetismo}

Nesta subseção ${ }^{16}$, analisamos o resultado do modelo de regressão logística ajustado com variáveis instrumentais (ver "Nota metodológica" no Apêndice), cuja finalidade foi estimar o impacto das variáveis avaliação do governo Dilma e gosta do $P S D B$ sobre a probabilidade de um eleitor ser ou não ser identificado como antipetista.

Optamos por ajustar um modelo em dois estágios em função da relação de endogeneidade identificada para algumas das variáveis no modelo. Por exemplo, ser ou não ser antipetista pode exercer influência na avaliação que um eleitor realiza sobre o governo e vice-versa. O viés produzido por essa relação problemática pode ser tratado utilizando variáveis instrumentais (IV) para cada variável endógena incluída no modelo (Angrist e Pischke, 2008). Estratégias semelhantes também foram adotadas por Samuels e Zucco (2014).

Em modelos de múltiplos estágios com variáveis instrumentais, o primeiro objetivo é encontrar uma terceira variável, chamada de variável instrumental, que esteja correlacionada à variável explicativa endógena, mas que não esteja correlacionada com a variável resultado. O método consiste na utilização da variável adicional para estimar uma nova variável que substituirá a variável explicativa problemática no modelo. Portanto, a análise incorpora aspectos de um sistema de duas equações estimadas isoladamente, mas que o resultado final acaba incorporando as inter-relações entre as variáveis naquele sistema.

Em primeiro lugar, é preciso olhar os coeficientes estimados com cuidado. As variáveis instrumentais utilizadas para corrigir o viés nas variáveis endógenas podem ser consideradas instrumentos fracos. Isso significa que os instrumentos têm uma baixa correlação com as variáveis endógenas e que alguma correlação com a variável dependente não pode ser descartada; o que pode produzir uma variância nos coeficientes estimados relativamente larga (Bound, Jaeger e Baker, 1995). Todavia, a nossa aposta é de que o tratamento das variáveis endógenas produza mais benefícios do que um eventual declínio de precisão em seus coeficientes.

Foram ajustados vários modelos avaliando diferentes dimensões do sentimento antipetista. Nem todas as variáveis de interesse, contudo, foram mantidas no modelo, principalmente porque havia a necessidade de combater a sobreposição de efeitos, a multicolinearidade e a perda excessiva de graus de liberdade. O que poderia acabar inflando os erros residuais ao incluir parâmetros adicionais no modelo. Por esse motivo também a presente análise se concentra em explorar apenas os efeitos principais das

\footnotetext{
${ }^{16}$ Agradecemos a contribuição de Max Stabile e a consultoria de Daniel Marcelino Silva na construção dos modelos estatísticos.
} 
variáveis. A Tabela 10 apresenta os resultados do modelo ajustado para compreensão do sentimento antipetista:

Tabela 10

Coeficientes estimados para o sentimento antipetista

\begin{tabular}{|c|c|c|c|c|}
\hline & \multicolumn{4}{|c|}{ Variável dependente } \\
\hline & Antipetismo & Antipetismo & Antipetismo & Antipetismo \\
\hline & Modelo 1 & Modelo 2 & Modelo 3 & Modelo 4 \\
\hline & $B(E P)$ & $B(E P)$ & $B(\mathrm{EP})$ & $B(\mathrm{EP})$ \\
\hline Intercepto & $-3.82(0.55)^{* * *}$ & $-2.97(0.45)^{* * *}$ & $-2.57(0.14)^{* * *}$ & $-3.85(0.51)^{* * *}$ \\
\hline Aval-Dilma-IV & & & $-1.54(0.26)^{* * *}$ & $-1.53(0.26)^{* * *}$ \\
\hline $\begin{array}{c}\text { Gosta-PSDB- } \\
\text { IV }\end{array}$ & & & $1.62(0.19)^{* * *}$ & $1.58(0.19)^{* * *}$ \\
\hline $\begin{array}{c}\text { Gosta-Dilma- } \\
\text { IV }\end{array}$ & & & $-1.23(0.33)^{* * *}$ & $-1.13(0.34)^{* * *}$ \\
\hline Expectativa & $0.13(0.17)$ & & & \\
\hline Democracia & $-0.09(0.09)$ & & & \\
\hline Vota-PT & $0.23(0.37)$ & & & \\
\hline Vota-PSDB & $0.24(0.21)$ & & & \\
\hline Gosta-PSDB & $0.23(0.10)^{*}$ & & & \\
\hline Gosta-Aécio & $0.35(0.11)^{* *}$ & & & \\
\hline Aval-Dilma & $-0.39(0.10)^{* * *}$ & & & \\
\hline Gosta-Dilma & $-1.37(0.14)^{* * *}$ & & & \\
\hline \multicolumn{5}{|c|}{ Variáveis de Controle } \\
\hline Feminino & $0.15(0.17)$ & $0.10(0.16)$ & & $0.15(0.18)$ \\
\hline Idade & $0.19(0.09)^{*}$ & $0.02(0.09)$ & & $0.07(0.09)$ \\
\hline Idade2 & $0.12(0.08)$ & $0.15(0.08)$ & & $0.15(0.08)$ \\
\hline Cor & $-0.03(0.18)$ & $-0.27(0.17)$ & & $-0.07(0.19)$ \\
\hline Superior & $0.33(0.25)$ & $0.48(0.23)^{*}$ & & $0.50(0.26)^{*}$ \\
\hline Região-NE & $0.28(0.50)$ & $0.27(0.41)$ & & $0.60(0.44)$ \\
\hline Região-N & $-0.25(0.66)$ & $-0.67(0.56)$ & & $-0.46(0.59)$ \\
\hline Região-SE & $0.14(0.45)$ & $0.42(0.38)$ & & $0.49(0.41)$ \\
\hline Região-S & $-0.14(0.50)$ & $0.61(0.42)$ & & $0.54(0.45)$ \\
\hline Renda & $0.31(0.16)^{*}$ & $0.54(0.14)^{* * *}$ & & $0.49(0.16)^{* *}$ \\
\hline
\end{tabular}




\begin{tabular}{|c|c|c|c|c|}
\hline \multicolumn{5}{|c|}{ Variável dependente } \\
\hline AIC & 986.00 & 916.12 & 757.70 & 749.97 \\
\hline BIC & 1089.88 & 976.27 & 779.57 & 826.51 \\
\hline Log Likelihood & -474.00 & -447.06 & -374.85 & -360.98 \\
\hline Deviance & 948.00 & 1035.49 & 878.72 & 846.83 \\
\hline McFadden & .37 & .05 & .20 & .23 \\
\hline Num. obs. & 1750 & 1750 & 1750 & 1750 \\
\hline
\end{tabular}

Nota: As variáveis Aval-Dilma-IV, Gosta-PSDB-IV, Gosta-Dilma-IV são endógenas. Para a primeira, os instrumentos utilizados foram: Expectativa e Democracia. Para a segunda, os instrumentos foram: GostaAécio e Vota-PSDB. Para a variável Gosta-Dilma-IV, o instrumento utilizado foi Vota-PT (ver detalhamento em "Nota metodológica", no Apêndice).

Significância: $\mathrm{p}<0.001(* * *), \mathrm{p}<0.01(* *), \mathrm{p}<0.05(*)$.

Abreviações: EP - Erro-Padrão; AIC - Akaike Information Criterion; BIC - Bayesian Information Criterion.

O modelo 1 traz todas as variáveis, endógenas e instrumentais, usadas no delineamento dos demais modelos, e, portanto, não tenta corrigir as variáveis endógenas. Todas as variáveis entram juntas e ao mesmo tempo no modelo. 0 modelo 2 traz apenas as variáveis de controle sociodemográficas, permitindo uma comparação visual da significância estatística dessas covariáveis. O modelo 3 foi ajustado apenas com as variáveis explicativas endógenas, após o tratamento com as variáveis instrumentais. Por fim, o modelo 4 apresenta os coeficientes estimados dessas mesmas variáveis endógenas após o tratamento, mas também controlados pelas variáveis sociodemográficas; portanto, nosso modelo final.

No que diz respeito ao ajuste global do modelo, embora o modelo 1 apresente um pseudo- $\mathrm{R}^{2}$ maior (McFadden $=0.37$ ) em comparação ao modelo com variáveis instrumentais (McFadden $=0.23$ ), é preciso dizer que o principal objetivo dessa análise não é o de obter o maior $\mathrm{R}^{2}$, mas de estimar valores mais consistentes para as variáveis de interesse. Além disso, a discussão em torno dessa métrica, quando aplicada a modelos não lineares, tende a gerar mais confusão do que certezas, especialmente em leitores acostumados a interpretar $0 \mathrm{R}^{2}$ de regressões lineares, como se a única coisa importante num modelo fosse o montante de "variância explicada". Como apontam Hosmer e Lemeshow (2005, p. 167), valores de pseudo- $\mathrm{R}^{2}$ baixos são a norma em modelos logísticos, motivo pelo qual os autores sugerem que essa métrica não devesse ser mencionada. Ainda assim, uma conclusão é possível olhando para esses números ao final da Tabela 10: as variáveis sociodemográficas explicam muito pouco a mudança na variável dependente (McFadden $=0.05)$. Já o modelo contendo as três variáveis endógenas explicaria quatro vezes mais que o modelo ajustado apenas com as variáveis sociodemográficas. Dentre estas, apenas Renda e Ensino Superior exercem algum efeito 
estatisticamente significativo, indicando que o eleitor com renda familiar mensal acima de cinco salários mínimos e com a escolaridade mínima de Ensino Superior possui mais chance de ser antipetista do que aquele com renda familiar mensal de até cinco salários mínimos e com a escolaridade máxima de Ensino Médio. Outras estatísticas também sugerem que o modelo 4 é o melhor modelo na Tabela 10, uma vez que modelos com menor valor para AIC (Akaike Information Criterion), BIC (Bayesian Information Criterion) e Deviance, em geral, são preferidos.

No tocante aos principais resultados encontrados, a análise dos coeficientes demonstra que todos eles apresentam os sinais nas direções previstas. Portanto, não há efeitos inesperados ou contraintuitivos produzidos pelo arranjo das variáveis na regressão.

O coeficiente estimado para a variável Aval-Dilma-IV indica que quem avalia negativamente o governo Dilma - dadas a expectativa do eleitor de que a sua renda familiar seja reduzida nos próximos 12 meses e a avaliação que ele faz do funcionamento da democracia no país - aumenta as chances de ser antipetista em comparação àquele que avalia positivamente o desempenho do governo. Dito de outra forma, quanto mais positivamente o eleitor avalia o desempenho do governo Dilma, menor é a chance de esse eleitor ser identificado como antipetista. O Gráfico 1 fornece uma interpretação visual dessa relação para alguns níveis de avaliação do governo Dilma (Aval-Dilma-IV). Na Tabela 10, os valores estão em escala logarítmica, mas se convertidos para a escala exponencial para refletir a razão de chances $(\operatorname{Exp}(B))$, o valor estimado é de 0.20, significando que, para cada alteração de unidade na escala, as chances proporcionais de o respondente ser identificado como antipetista aumentam 0.20 vez. Embora esse valor pareça pequeno, a diferença entre um eleitor que avalia o governo Dilma como péssimo $(-2)$ para um outro que o avalia como ótimo $(+2)$ é de aproximadamente: $(-1.533-1) \times$ $100 \%=458 \%$, dado que as demais variáveis permaneçam constantes. Uma diferença não tão pequena, afinal. 
Gráfico 1

Probabilidade de ser antipetista conforme a avaliação do governo Dilma e o sentimento em relação a Dilma

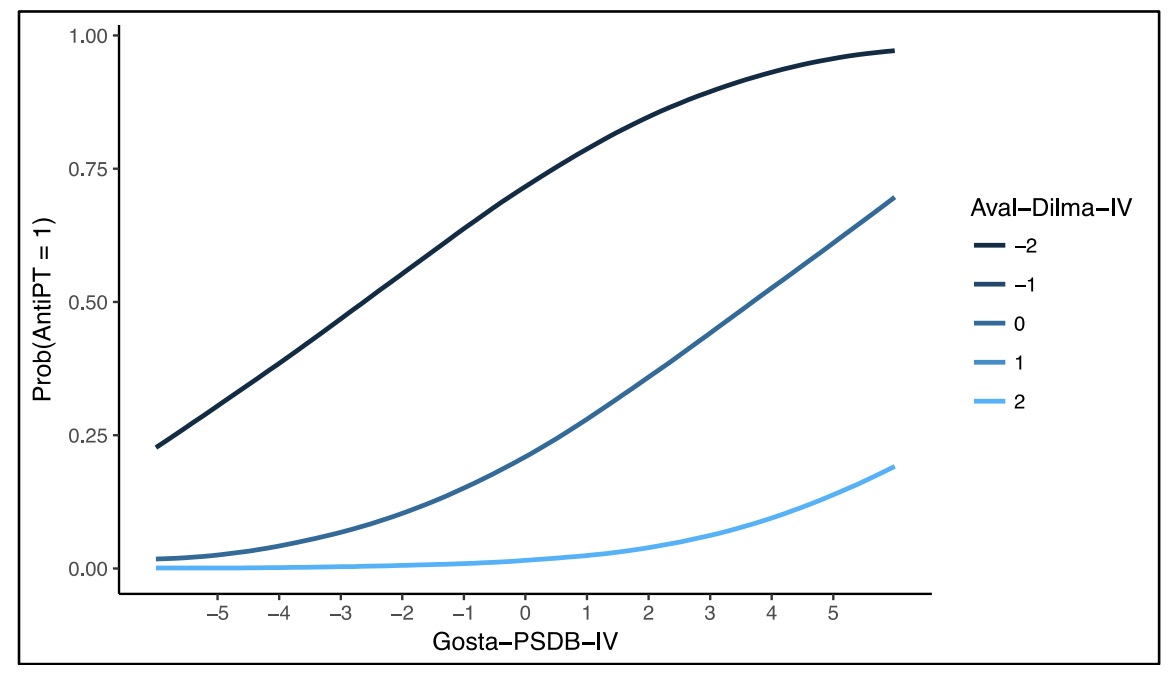

Além de demonstrar que quem avalia o governo Dilma como ótimo (linha inferior, próxima ao eixo $\mathrm{x}$ ) tem pouquíssimas chances de ser antipetista - sendo 0.00 a 0.50 igual à probabilidade de não ser antipetista e 0.51 a 1.00 igual à probabilidade de ser antipetista -, os valores estimados também atestam que quem respondeu não gostar de jeito nenhum de Dilma (-5) tem maiores chances de ser antipetista (resultados próximos ao eixo y para todas as linhas), chances essas que aumentam conforme a avaliação do governo Dilma torna-se mais negativa (linha superior, mais afastada do eixo $\mathrm{x}$ ).

O coeficiente estimado para a variável Gosta-PSDB-IV corrobora que aquele eleitor que expressa alguma ou alta simpatia pelo PSDB - dado que também gosta de Aécio Neves e que votou nos candidatos do PSDB à presidência nas eleições de 2010 e 2014 - possui 4.9 (valor convertido para a escala exponencial) vezes mais chances de ser antipetista do que aquele que expressa baixa ou nenhuma simpatia pelo partido, por Aécio Neves e não votou nos candidatos apresentados pelo PSDB nos dois turnos das eleições presidenciais de 2010 e 2014. A relação entre gostar do PSDB e a probabilidade de ser antipetista fica mais clara olhando o Gráfico 2: 


\section{Gráfico 2}

Probabilidade de ser antipetista conforme o sentimento em relação ao PSDB e a avaliação do governo Dilma

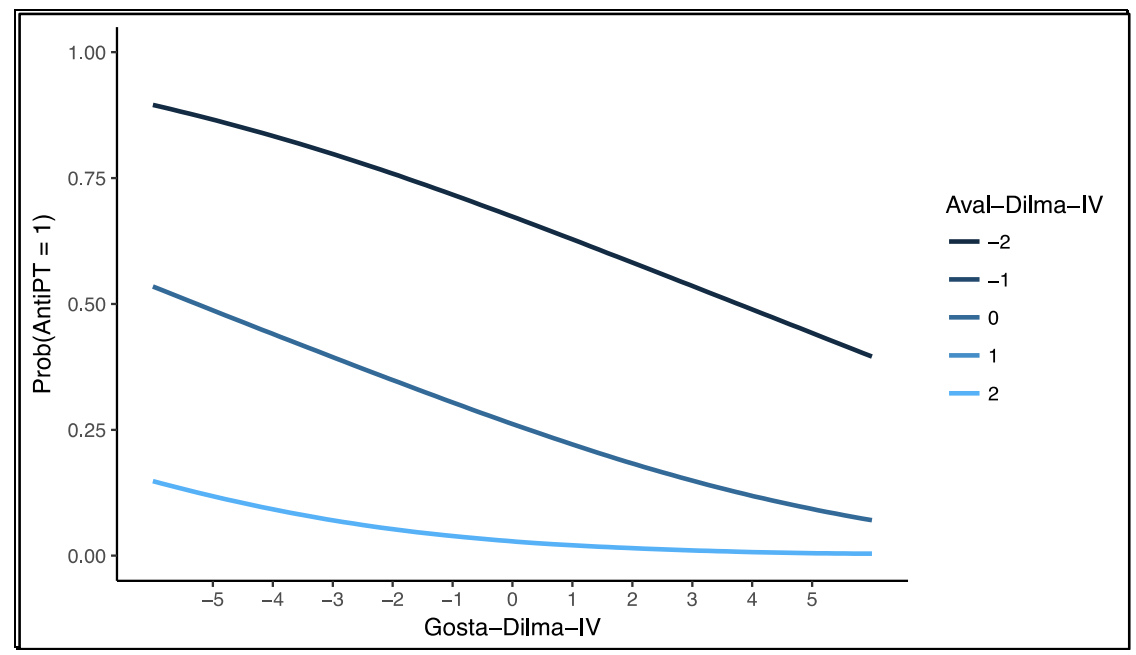

O Gráfico 2 demonstra que, conforme aumenta o sentimento positivo do eleitor em relação ao PSDB (sendo $+5=$ gosta muito), crescem também as chances de ele ser antipetista e, quanto mais negativa é a sua avaliação acerca do governo Dilma, maior é a probabilidade de ele ser antipetista.

Ressaltamos, ainda, que a variável gosta do PSDB (Gosta-PSDB-IV) contém uma dispersão dos erros padronizados menor que a variação encontrada para o efeito da avaliação do governo, de modo que o seu impacto parece ser mais preciso entre os eleitores que o encontrado para a variável anterior (Aval-Dilma-IV), conforme ilustra o Gráfico 3: 
Gráfico 3

Coeficientes estimados convertidos para a escala exponencial $(\operatorname{Exp}(B))$

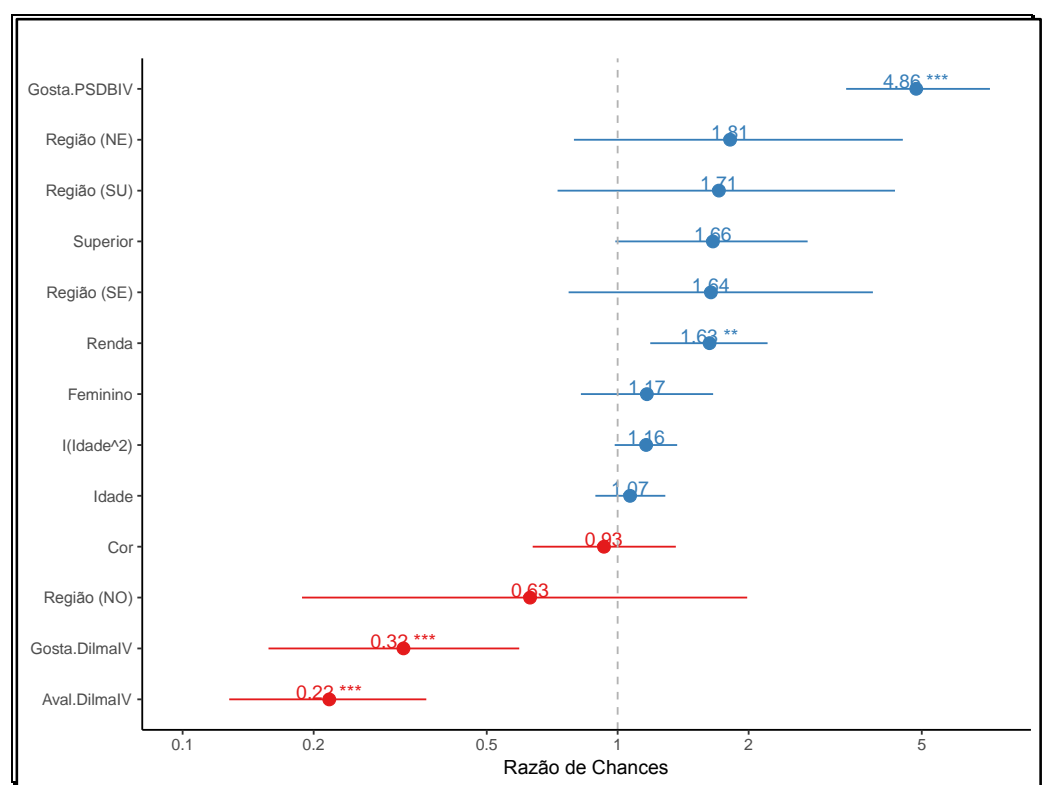

A terceira variável endógena relacionada com o antipetismo e considerada na análise é o sentimento em relação a Dilma Rousseff (Gosta-Dilma-IV). O sinal negativo do coeficiente sugere que eleitores que declaram gostar de Dilma apresentam 0.31 menos chances de serem identificados como antipetista do que aqueles que respondem não gostar de jeito nenhum. Mais uma vez, se considerada a escala de 11 pontos para essa variável, as chances de um eleitor que declarou "não gosto de jeito nenhum" de Dilma (-5) ser identificado como antipetista, em relação a um outro que disse "gostar muito" (+5), são bem maiores: $(-1.1310-1) \times 100 \%=439 \%$.

Os resultados apresentados, portanto, confirmam as nossas hipóteses, de que o antipetista é o eleitor que avalia negativamente o governo da presidente Dilma Rousseff e que possui algum sentimento positivo pelo PSDB (gosta ou gosta muito do partido), além de demonstrar preferência política pelos candidatos desse partido. 


\section{Considerações finais}

É preciso lembrar, novamente, que tanto a rejeição a todos os partidos como a rejeição a uma legenda específica são temas ainda pouco investigados no caso brasileiro. Entendemos que o antipartidarismo e a identidade partidária negativa são constituídos por múltiplas facetas, sendo necessário distinguir suas diversas manifestações. A literatura também tem destacado que a identidade partidária negativa pode ser a manifestação do "outro lado de uma mesma moeda", ou seja, de um partidarismo, sinalizando uma polarização.

Neste artigo, propusemo-nos a investigar especificamente o antipetista, identificado como aquele sujeito que rejeita exclusivamente e radicalmente a legenda, partindo da compreensão de que há um eleitor que tem apresentado um partidarismo negativo, isolando-o do que é entendido como o antipartidário, eleitor que rejeita genericamente todos os partidos.

A separação dos entrevistados que indicaram nota 0 ao PT em dois grupos distintos mostrou-se adequada, pois constatamos, a partir da análise de variáveis de diversas naturezas, que o antipartidário diferencia-se do antipetista. São dois sujeitos diferentes não somente no que diz respeito ao perfil socioeconômico, mas também em seu posicionamento em relação aos partidos, sua autolocalização na escala ideológica esquerda-centro-direita, na decisão do voto para presidente, na avaliação de governo e de lideranças políticas e na prospecção de futuro da economia no país.

Tratando-se especificamente do antipetista, pode-se resumir o seu perfil como sendo um eleitor predominantemente de cor branca, de maior escolaridade, maior renda familiar mensal e de estratos sociais mais elevados. É um eleitor que tem preferência partidária pelo PSDB e, inclusive, possui uma aproximação ideológica com esse partido, pois se autolocaliza na escala ideológica na posição de centro-direita a direita e identifica essa legenda como estando na mesma posição ideológica. Além disso, ele faz uma avaliação negativa do governo Dilma Rousseff (PT) e da economia do país. Cabe ressaltar, por fim, que o antipetismo é um fenômeno localizado predominantemente no Sudeste, principalmente, no estado de São Paulo.

Os resultados do modelo de regressão logística ajustado com variáveis instrumentais revelaram-nos alguns achados. Foi possível detectar que o antipetista traduz uma avaliação negativa em relação ao governo Dilma, influenciada, retrospectivamente, por sua insatisfação com o funcionamento da democracia e, prospectivamente, pela expectativa de que sua renda familiar seja reduzida nos próximos 12 meses. Observou-se que quanto mais negativo o eleitor avaliasse o desempenho do governo Dilma, maior era a chance de ele ser identificado como antipetista.

Também possibilitou-nos constatar o perfil partidarizado que define o antipetista, pois foi demonstrado que quem gosta do PSDB, dado que também gosta de Aécio e que 
vota nos candidatos do PSDB, tem maior probabilidade de ser antipetista. Por outro lado, buscando o inverso, os eleitores que gostam de Dilma, visto que também votaram nela para presidente em 2010 e 2014 , têm menores chances de ser antipetistas.

Portanto, nossas duas hipóteses iniciais foram confirmadas, ressaltando-se que a variável que detecta o partidarismo (GostaPSDB) possui maior precisão de predição do que a variável avaliação do governo Dilma.

Por fim, destacamos a existência de uma profícua agenda de pesquisa para trabalhos futuros, que consistirá não só em aprofundar a investigação sobre o antipetismo, mas também sobre a ampliação do antipartidarismo, do partidarismo negativo e suas implicações não só para a política partidária, como também para os rumos da democracia em nosso país.

Denise Paiva - Faculdade de Ciências Sociais, Universidade Federal de Goiás.

E-mail: <denise@ufg.br>.

Silvana Krause - Departamento de Ciência Política, Instituto de Filosofia e Ciências Humanas, Universidade Federal do Rio Grande do Sul. E-mail: <krausesilvana@yahoo.com.br>.

Adriana Paz Lameirão - Doutoranda no Programa de Pós-Graduação em Ciência Política, Instituto de Filosofia e Ciências Humanas, Universidade Federal do Rio Grande do Sul. E-mail: <adri_paz@yahoo.com.br>.

\section{Referências bibliográficas}

Aarts, K.; Blais, A.; Schmitt, H. (eds.). Political leaders and democratic elections. Oxford: Oxford University Press, 2013.

AmARAL, O. "As transformações na organização interna do Partido dos Trabalhadores". Tese de Doutorado, Programa de Pós-Graduação em Ciência Política, Unicamp, Campinas, 2010.

ANGRIST, J. D.; KRUeger, A. B. "Does compulsory school attendance affect schooling and earnings?". The Quarterly Journal of Economics, vol. 106, no 4, p. 979-1.014, 1991. Disponível em:

<http://doi.org/10.2307/2937954>. Acesso em: 15 out. 2016.

ANGRIST, J. D.; PISCHKE, J. S. Mostly harmless econometrics: an empiricist's companion. Princeton: Princeton University Press, 2008.

BALBACHEWSKY, E. "Identidade partidária e instituições políticas no Brasil". Lua Nova, no 26, p. 133$66,1992$.

BALBACHEWSKY, E.; HOLZHACKER, D. O. "Identidade, oposição e pragmatismo: o conteúdo estratégico da decisão eleitoral em 13 anos de eleições". Opinião Pública, Campinas, vol. X, no 2, p. 242-253, 2004.

BARTOLINI, S.; MAIR, P. Identity, competition and electoral availability: the stabilisation of European electorates, 1885-1985. New York: Cambridge University Press, 1990. 
BAQUERo, M.; LinhaRES, B. F. "Por que os brasileiros não confiam nos partidos? Bases para compreender a cultura (anti)partidária e possíveis saídas". Revista Debates, vol. 5, nº 1, p. 89-114, 2011.

BlaIS, A. Political leaders and democratic elections. In: AARTS, K.; BLAIS, A.; SCHMITT, H. (eds.). Political leaders and democratic elections. Oxford: Oxford University Press, 2013.

BOUND, J.; JAEGER, D. A; BAKER, R. "The cure can be worse than the disease: a cautionary tale regarding instrumental variables". NBER Technical Paper Series, p. 1-23, 1995. Disponível em: <http://www.nber.org/papers/t0137.pdf>. Acesso em: 15 out. 2016.

BragA, M. S.; Pimentel JR., J. "Os partidos políticos brasileiros realmente não importam?". Opinião Pública, vol. 17, no 2, p. 271-303, nov. 2011.

CAmpBeLL, A., et al. The American voter. New York: John Wile, 1960.

CARreirão, Y. "Opiniões políticas e sentimentos partidários dos eleitores brasileiros". Opinião Pública, vol. 14, no 2, p. 319-351, nov. 2008.

CARREIRÃo, Y.; Kinzo, M. D. G. "Partidos políticos, preferência partidária e decisão eleitoral no Brasil". Dados, vol. 47, p. 131-168, 2004.

CÉSAR, B. T. PT: a contemporaneidade possível - base social e projeto político (1980-1991). Porto Alegre: Editora da UFRGS, 2002.

CONVERSE, P. The nature of belief systems in mass publics. In: APTER, D. (ed.). Ideology and discontent. New York: The Free Press of Glencoe, 1964.

DALTON, R.; MCALlister, I.; WATtenBerg, M. The consequences of partisan dealignment. In: DALTON, R.; WATtenberg, M. (eds.). Parties without partisans. Political change in advanced industrial democracies. Oxford: Oxford University Press, p. 37-63, 2002.

. "Democracia e identificação partidária nas sociedades industriais avançadas". Análise Social, vol. XXXVIII, no 167, p. 295-320, 2003.

DesCHOUWER, K. "Political parties and democracy: a mutual murder?". European Journal of Political Research, vol. 29, p. 263-278, 1996.

Downs, A. An economic theory of democracy. New York: Harper \& Row Publisher, 1957.

DRUCKER, P. Sociedade pós-capitalista. São Paulo: Pioneira, 1993.

FIORINA, M. Retrospective voting in American national elections. New Haven: Yale University Press, 1981.

Gimenes, E. R., et al. "Partidarismo no Brasil: análise longitudinal dos condicionantes da identificação partidária (2002-2014)". Revista Debates, vol. 10, n 2, p. 121-148, 2016.

GReENE, S. "Understanding party identification: a social identity approach". Political Psychology, vol. 20, no 2, p. 393-401, 1999.

Greene, W. H. Econometric analysis. New York: New York University/ Pearson Education, Inc., 2008. Himmeweit, H., et al. How voters decide. London: Academic Press Incorporation Ltda., 1981.

Hosmer JR., D. W.; LemeShow, S. Applied logistic regression. New York: Wiley, 2005. 
IGNAZI, P. "Power and the (il) legitimacy of political parties: an unavoidable paradox of contemporary democracy?". Party Politics, vol. 20, no 2, p. 160-169, 2014.

Hunter, W. Corrupção no Partido dos Trabalhadores. O dilema do "sistema". In: NicolaU, J.; POWER, T. Instituições representativas no Brasil. Balanço e reforma. Belo Horizonte/Rio de Janeiro: Ed. UFMG/Iuperj/Ucam, p. 155-167, 2007.

KATZ, R.; MAIR, P. How parties organize. Change and adaptation in party organizations in Western democracies. London: Sage Publications, 1994.

KECK, M. The Workers' Party and democratization in Brazil. New Haven: Yale University Press, 1992.

KEITH, B., et al. The myth of the independent voter. Berkeley: University of California Press, 1992.

KESTILÄ-KEKKONEN, E. "Anti-party sentiments among young adults. Evidence from fourteen West European countries". Young, vol. 17, no 2, p. 145-165, 2009.

KINZO, M. D. G. "A eleição presidencial brasileira de 1989: o comportamento eleitoral em uma cidade brasileira". Dados, vol. 35, no 1, p. 49-66, 1992.

. "Os partidos no eleitorado: percepções públicas e laços partidários no Brasil". Revista Brasileira de Ciências Sociais, vol. 20, no 57, p. 65-81, 2005.

Kosiara-Pedersen, K.; Scarrow, S.; Van Haute, E. "Rules of engagement? Party membership costs, new forms of party affiliation, and partisan participation". Paper presented at ECPR General Conference, Montreal, 26-29 August, 2015. Disponível em:

<https://ecpr.eu/Filestore/PaperProposal/6a8a0774-2d50-4a79-a291-41a3de903dd8.pdf>. Acesso em: 15 set. 2016 .

LACERDA, A. D. F. "O PT e a unidade partidária como um problema". Dados, vol. 45, no 1, p. 39-46, 2002.

LAVAreda, A. "Governos, partidos e eleições segundo a opinião pública. O Brasil de 1989 comparado ao de 1964". Dados, vol. 32, no 3, p. 341-362, 1989.

LAWSON, K.; MERKL, P. When parties fail: emerging alternative organizations. Princeton: Princeton University Press, 1988.

LiPow, A.; SeYd, P. "The politics of anti-partyism". Parliamentary Affairs, vol. 49, no 2, p. 273-284, April, 1996.

MAINWARING, S. Rethinking party systems in the third wave of democratization: the case of Brazil. Stanford: Stanford University Press, 1999.

MAIR, P. "Os partidos políticos e a democracia". Análise Social, vol. XXXVIII, no 167, p. 277-293, 2003.

MANIN, B. "As metamorfoses do governo representativo". Revista Brasileira de Ciências Sociais, vol. 10 , no 29 , p. 5-34, 1995.

Martins JR., J. P. "Modelo sociológico de decisão de voto presidencial no Brasil 1994-2006". Revista Debates, vol. 3, no 2, p. 68-96, 2009.

Medeiros, M; NöEL, A. "The forgotten side of partisanship: negative party identification in four Anglo-American democracies". Comparative Political Studies, vol. 47, no 7, p. 1.022-1.046, 2014. 
Meneguello, R. PT: a formação de um partido 1979-1982. Rio de Janeiro: Paz e Terra, 1989.

MoISÉS, J. A.; CARNEIRO, G. P. "Sobre o enraizamento dos partidos na sociedade brasileira". Interesse Nacional, no 28, 2014. Disponível em: <http://interessenacional.com/index.php/edicoesrevista/sobre-o-enraizamento-dos-partidos-politicos-na-sociedade-brasileira-2/>. Acesso em: 21 mar. 2016.

NORRIS, P. Democratic Phoenix: reinventing political activism. Cambridge: Cambridge University Press, 2002.

Paiva, D.; Braga, M. S. S.; Pimentel JR., J. "Eleitorado e partidos políticos no Brasil". Opinião Pública, vol. 13, no 2, p. 388-408, nov. 2007.

PAIVA, D.; TAROUCO, G. "Voto e identificação partidária: os partidos brasileiros e a preferência dos eleitores". Opinião Pública, no 2, vol. 17, p. 426-45, 2011.

Pedersen, H.; Scarrow, S.; Van Haute, E. "Rules of engagement? Party membership costs, new forms of party affiliation, and partisan participation". Paper presented at ECPR General Conference, Montreal, August 2015. Disponível em: <http://www.politicalpartydb.org/working-papers/>. Acesso em: mar. 2016.

PogUNTKE, T.; SCARROW, S. "The politics of anti-party sentiment: Introduction". European Journal of Political Research, vol. 29, no 3, p. 257-262, 1996.

POMPER, G. Voter's choices. New York: Harper \& Row, 1975.

POPKIN. S. The reasoning voter. Chicago: The University of Chicago Press, 1994.

Ribeiro, E.; CARReirÃo, Y.; Borba, J. "Sentimentos partidários e atitudes políticas entre brasileiros". Opinião Pública, vol. 17, n 2, p. 333-368, nov. 2011.

Ribeiro, P. F. O Partido dos Trabalhadores e a política brasileira (1980-2006). São Carlos: Editora da UFSCar, p. 183-217, 2009.

ROSE, R.; MISHLER, W. "Negative and positive party identification in post-communist countries". Electoral Studies, vol. 17, no 2, p. 217-234, 1998.

Samuels, D. "As bases do petismo". Opinião Pública, Campinas, vol. 10, nº 2, p. 221-241, 2004. p. 1-27, 2006.

. "Sources of mass partisanship in Brazil". Latin American Politics and Society, vol. 48, n 1 , $318,2008$.

. "A evolução do petismo (2002/2008)". Opinião Pública, Campinas, vol. 14, no 2, p. 302-

SAmuels, D.; Zucco, C. "Lulismo, petismo and the future of Brazilian politics". Journal of Politics in Latin America, vol. 6, n 3, p. 129-158, 2014.

. "Partisans, anti-partisans and voting behavior in Brazil". Paper apresentado no Encontro da American Political Science Association (APSA), San Francisco, 2-6 de setembro, 2015.

SARTORI, G. Partidos e sistemas partidários. Brasília: Editora da UnB, 1982. 
Scarrow, S. Parties without members? In: Dalton, R. J.; Wattenberg, M. P. (eds.). Parties without partisans. Political change in advanced industrial democracies. Oxford: Oxford University Press, p. 79-101, 2000.

Beyond party members: changing approaches to partisan mobilization. London: Oxford University Press, $2015 a$.

. "Boosting partisan engagement by re-thinking party membership", 2015b. Disponível em: <http://21cparties.org/post/138934648583/boosting-partisan-engagement-by-re-thinking-party >. Acesso em: mar. 2016.

SCHмIT, H. "On party attachment in Western Europe and the utility of the Eurobarometer data". West European Politics, vol. 12, p. 122-139, 1989.

SCHMitTer, P. Parties are not what they once were. In: Diamond, L.; Gunther, R. (eds.). Political parties and democracy. Baltimore: Johns Hopkins University Press, 2001.

Silveira, F. A decisão de voto no Brasil. Porto Alegre: Editora PUC-RS, 1998.

Singer, A. Esquerda e direita no eleitorado brasileiro. São Paulo: Edusp, 2000.

TAtagiba, L.; Trindade, T.; Chaves Teixeira, A. C. Protestos à direita no Brasil - 2007/2015. In: Velasco e Cruz, S.; KAYSEL, A.; CodAs, G. (orgs.). Direita, volver! O retorno da direita no ciclo político brasileiro. São Paulo: Fundação Perseu Abramo, p. 197-212, 2015.

TELLES, H. S. "Corrupção, legitimidade democrática e protestos; o boom da direita política nacional". Interesse nacional, no 30, p. 28-46, 2015a. Disponível em:

$<$ http://interessenacional.com/index.php/edicoes-revista/corrupcao-legitimidade-democratica-eprotestos-o-boom-da-direita-na-politica-nacional/>. Acesso em: 26 mar. 2016.

. "Corrupção, antipetismo e nova direita: elementos da crise político institucional".

GVExecutivo, vol. 14, no 2, p. 37-39, 2015 b.

Teixeira, C. P.; TSATSAnis, E.; Belchior, A. M. "A 'necessary evil' even during hard times? Public suport for political parties in Portugal before and after the bailout". Party Politics, vol. 20, no 2, p. 160-169, 2014.

Torcal, M.; Gunther, R.; Montero, J. R. "Anti-party sentiments in Southern Europe". Working Paper, no $170,2001$.

VEIGA, L. "Os partidos brasileiros na perspectiva dos eleitores: mudanças e continuidades na identificação partidária e na avaliação das principais legendas após 2002". Opinião Pública, vol. 13, no 2, p. 340-365, 2007.

Venturi, G. PT 30 anos: crescimento e mudanças na preferência partidária. São Paulo: Fundação Perseu Abramo, 2010. Disponível em:

<http://novo.fpabramo.org.br/sites/default/files/6.perseu5.venturi.pt30.pdf>. Acesso em: 15 mar. 2016.

Villa, M. A., et al. (orgs.). Uma história revisitada: o Partido dos Trabalhadores e a política brasileira (1980-2006). São Carlos: Editora da UFSCar, 2009.

WATtEnBERG, M. Without partisans: political change in advanced industrial democracies. Oxford: Oxford University Press, 2002. 
WHITELEY, P. "Is the party over? The decline of party activism and membership across the democratic world". Party Politics, vol. 17, no 1, p. 21-44, 2011.

ZeLLE, C. "Social dealignment vs. political frustration: contrasting explanations of the floating vote in Germany". European Journal of Political Research, vol. 27, p. 319-345, 1995.

\author{
Apêndice \\ Nota metodológica \\ $1-O$ Eseb
}

O Estudo Eleitoral Brasileiro (Eseb) é um survey pós-eleitoral que se iniciou em 2002; as demais ondas foram realizadas em 2006, 2010 e a mais recente em 2014. O Eseb integra o consórcio internacional Comparative Studies of Electoral Systems (CSES), coordenado pela Universidade de Michigan, contendo em todas as edições um módulo comum aos integrantes do projeto bem como um conjunto de questões definidas e elaboradas por pesquisadores brasileiros. $O$ Eseb 2014 foi coordenado pelo Centro de Estudos de Opinião Pública (Cesop) da Universidade Estadual de Campinas. O trabalho de definição da amostra e de campo foi conduzido pelo Instituto Brasileiro de Opinião Pública e Estatística (Ibope). A amostra nacional contou com 2.506 entrevistas com eleitores e o trabalho de campo foi realizado no período compreendido entre $1^{\circ}$ e 19 de novembro de 2014.

\title{
2 - Modelo logístico
}

Em primeiro lugar, parece haver evidências de que um modelo moldado para explicar o antipetismo com base apenas em variáveis de survey (e que não foi desenhado exclusivamente para essa tarefa) apresenta alguns limites, entre os quais: i) omissão de variáveis que medisse de maneira mais apropriada o fenômeno do sentimento antipetista; ii) problemas com variáveis explicativas endógenas. Por exemplo, a avaliação do governo Dilma e a avaliação da atuação do governo federal não são variáveis tão independentes assim, uma vez que a avaliação do governo feita pelo eleitor pode estar sendo influenciada pelo desempenho macroeconômico do país, pelo seu próprio desempenho econômico individual, além da preferência partidário-ideológica do eleitor ou ainda do seu sentimento vis-à-vis a pessoa do presidente. Dito de outro modo, ser ou não antipetista pode estar exercendo influência sobre a avaliação do governo, e esta sobre o sentimento negativo dirigido ao PT. Assim, é preciso tentar diminuir ao máximo a estimação de todos esses efeitos em um mesmo coeficiente.

Uma suposição básica em análises de regressão é que o valor dos termos de erro da variável predita deve ser independente de suas variáveis preditoras. Quando essa suposição não é satisfeita, em casos de omissão de variáveis importantes para o modelo, erro de medição ou problemas de causalidade simultânea, ou reversa, o método de regressão com variáveis instrumentais é utilizado como uma forma de tentar reduzir os problemas citados, fornecendo estimadores mais consistentes das variáveis de interesse (Angrist e Krueger, 1991).

A ideia por trás da análise de variáveis instrumentais é encontrar uma terceira variável, chamada de variável instrumental, que possa ter afetado o grupo de respondentes, mas que não esteja correlacionada à variável resultado. Ou seja, essa técnica assume que existe uma segunda variável explicativa que está correlacionada à variável "explicativa endógena", mas não com seus termos de erro. O método consiste na utilização da variável adicional para estimar uma nova variável que substituirá a variável explicativa problemática (endógena) no modelo.

O método de regressão em dois estágios, portanto, incorpora aspectos de um sistema de duas equações estimadas isoladamente, de modo que o resultado final incorporaria todas as interrelações existentes naquele sistema. Vale ressaltar que a má especificação de uma equação propagaria o problema para todo o restante do sistema (Greene, 2008).

3 - Variáveis 
Variável dependente de interesse direto: se o eleitor é identificado como antipetista. Categorização: Antipetista $=1$ e Não Antipetista $=0$.

Variáveis explicativas utilizadas:

Aval.Dilma: avaliação do governo Dilma. Variável escalar com intervalo -2 a +2 ( -2 péssimo, -1 ruim, 0 regular, 1 bom, 2 ótimo). Gosta.Dilma: se o eleitor gosta ou não de Dilma. Variável escalar com intervalo -5 a +5 . Valores negativos representam baixa ou nenhuma simpatia por Dilma, enquanto valores positivos indicam alguma ou alta simpatia. Por definição, o ponto 0 indicaria indiferença em relação a ela. Gosta.PSDB: se o eleitor gosta ou não do PSDB. Variável escalar com intervalo $-5 a+5$. Da mesma forma que a variável anterior, valores negativos representam baixa ou nenhuma simpatia pelo partido, enquanto valores positivos sugerem alguma ou alta simpatia. $O$ ponto 0 indicaria indiferença em relação ao PSDB.

Variáveis instrumentais utilizadas:

Expectativa: variável binária, o valor 1 indica se o entrevistado acredita ser provável ou muito provável que a sua renda familiar vai ser reduzida nos próximos 12 meses. Democracia: satisfação com a democracia. Variável escalar com intervalo -2 a +2 . Valores negativos representam pouco ou nada satisfeito com a democracia no Brasil, enquanto valores positivos indicam satisfeito ou muito satisfeito. Por definição, o ponto 0 indicaria nem satisfeito, nem insatisfeito. Gosta.Aécio: se o eleitor gosta ou não de Aécio. Variável escalar com intervalo -5 a +5 (com 11 pontos). Valores negativos representam baixa ou nenhuma simpatia pelo político, enquanto valores positivos sugerem alguma ou alta simpatia. 0 ponto 0 indica indiferença em relação ao político. VotaPT: se o eleitor votou em Dilma Rousseff nas eleições presidenciais de 2010 e 2014. Variável binária, o valor 1 representa que o eleitor votou na candidata do PT nos dois turnos. VotaPSDB: se o eleitor votou nos candidatos do PSDB à presidência da República em 2010 e 2014. Variável binária, o valor 1 representa se o eleitor votou nos candidatos do PSDB, nos dois turnos.

Variáveis de controle utilizadas:

Feminino: Variável binária, o valor 1 representa se o entrevistado é do sexo feminino, 0 para masculino. Idade: Variável contínua, com intervalo entre 16 e 89 anos, o máximo. A fim de tornar os resultados mais simples, os valores dessa variável foram centrados e depois padronizados na sua média (41 anos), de modo que valores negativos indicam idade abaixo da média, e positivos, acima da média. A variável idade ao quadrado (Idade ${ }^{2}$ ) também foi incluída no modelo a fim de descrever eventuais relações não lineares entre idade e antipetismo. Superior: Variável binária, o valor 1 representa se o eleitor possui ao menos ensino superior, 0 para os demais casos. Renda: Variável ordinal com três níveis para o rendimento familiar; 1 (de 0 até 5 SM), 2 (mais de 5 até 10 SM), 3 (acima de $10 \mathrm{SM}$ ). Cor: Variável binária, o valor 1 representa se o entrevistado se declarou branco, 0 para os demais. Região: Variável categórica com cinco categorias representando as macrorregiões geográficas do país. Na equação, todas essas categorias entram como variáveis binárias, menos a categoria de referência (Centro-Oeste).

\section{Resumo}

\section{O eleitor antipetista: partidarismo e avaliação retrospectiva}

Há um grande número de estudos sobre o Partido dos Trabalhadores, abordando desde a sua origem, organização e dinâmica interna até a sua relação com o eleitorado. A legenda, ao longo dos anos, tem apresentado os maiores índices de preferência partidária vis-à-vis as demais, fenômeno esse conhecido como petismo. O artigo propõe-se a analisar a outra face desse fenômeno: a rejeição que parcela do eleitorado tem demonstrado a esse partido, o antipetismo. Queremos saber quem é o eleitor antipetista, com base nos dados do Estudo Eleitoral Brasileiro (Eseb) 2014. Nosso objetivo principal é identificar e caracterizar o perfil do eleitor antipetista, por meio da estatística descritiva, e estabelecer uma comparação com o eleitor antipartidário. Em seguida, recorrendo a um 
modelo de regressão logística ajustado, detectar o impacto de algumas variáveis sobre a probabilidade de o entrevistado ser identificado como antipetista. Os resultados mostraram que a avaliação negativa do desempenho do governo da presidente Dilma Rousseff e o voto nos candidatos do PSDB nas eleições presidenciais são variáveis determinantes para um eleitor ser antipetista.

Palavras-chave: preferência partidária; partidarismo; petismo; antipartidarismo; antipetismo

\section{Abstract \\ The antipetista voter: partisanship and retrospective evaluation}

There are a great number of studies on the Workers' Party (PT), addressing everything from its origin, organization, and internal dynamics to its relationship with the electorate. Over the years, the PT has enjoyed the largest party preference indices vis-à-vis other Brazilian political parties, a phenomenon known as petismo. This article proposes examining the other side of this situation: antipetismo or the rejection that a segment of the electorate has toward the PT. We want to know who the antipetista voter is, based on survey data from the 2014 Brazilian Electoral Study (ESEB). Our main goal is to identify and characterize the profile of the antipetista voter using descriptive statistics and establishing a comparison with the antiparty voter. We then use an adjusted logistic regression model to detect the impact of a set of variables on the probability that a respondent identifies as antipetista. The results show that the negative evaluation of President Dilma Rousseff's government performance and the vote for PSDB candidates in the presidential elections are decisive variables in determining a voter to be antipetista.

Keywords: party preference; partyism; petismo; antipartyism; antipetismo

\section{Resumen}

El elector antipetista: partidarismo y evaluación retrospectiva

Hay un número grande de estudios sobre el Partido de los Trabajadores, abordando desde su origen, organización y dinámica interna hasta su relación con el electorado. El partido, a lo largo de los años, ha presentado los mayores índices de preferencia partidaria vis a vis a las demás, fenómeno este, conocido como petismo. El artículo se propone el análisis de la otra fase de ese fenómeno: el rechazo que parte del electorado ha demostrado al partido, el antipetismo. Queremos saber quién es el elector antipetista, basado en los datos del Estudio Electoral Brasileño (Eseb) 2014. Nuestro objetivo principal es el de identificar y caracterizar el perfil del elector antipetista, por intermedio de la estadística descriptiva, y establecer una comparación con el antipartidario. En seguida, recurriendo a un modelo de regresión logística ajustado, detectar el impacto de algunas variables sobre la probabilidad de que el entrevistado sea identificado como antipetista. Los resultados mostraron que la evaluación negativa del desempeño del gobierno de la presidenta Dilma Rousseff, y el voto en el candidato del PSDB en las elecciones presidenciales son variables clave para que un votante sea antipetista.

Palabras clave: preferencia partidaria; partidarismo; petismo; antipartidarismo; antipetismo

\section{Résumé}

L'électeur anti-PT: esprit de parti et évaluation rétrospective

Il y a un grand nombre d'études à propos du Parti des Travailleurs (PT) qui traitent de son origine, son organisation et sa dynamique interne, à sa relation avec l'électorat. Tout au long de ces années, le PT a présenté les plus grands taux de préférence oartisane par rapport aux autres partis 
existants. Ce phénomène est connu comme petismo. L'article propose d'analyser l'autre face de ce phénomène: le rejet d'une partie de l'électorat envers ce parti, l'antipetismo. Nous désirons savoir qui est cet électeur anti-PT en nous basant sur les données de l'Étude Electorale Brésilienne (Eseb) de 2014. Notre objectif principal est d'identifier et de caractériser le profil de l'électeur anti-PT à partir de la statistique descriptive et d'établir une comparaison avec I'anti-partisan. Ensuite, nous ferons l'usage d'un modèle de régression logistique ajusté pour détecter l'impact de quelques variantes sur la probabilité que la personne interviewée soit identifiée comme anti-PT. Les résultats ont montré que l'évaluation négative de la performance du gouvernement de la présidente Dilma Rousseff et le vote pour le candidat du PSDB aux élections présidentielles sont des variables clés pour être un anti-PT.

Mots-Clés: préférence partisane; esprit de parti; petismo; anti-esprit de parti; antipetismo

Artigo submetido à publicação em março de 2016. Versão final aprovada em novembro de 2016. 